The University of Maine

DigitalCommons@UMaine

Spring 5-10-2019

\title{
Climate-Driven Migration: Prioritizing Cultural Resources Threatened by Secondary Impacts of Climate Change
}

Frankie St. Amand

University of Maine, anne.st@maine.edu

Follow this and additional works at: https://digitalcommons.library.umaine.edu/etd

Part of the Archaeological Anthropology Commons, and the Climate Commons

\section{Recommended Citation}

St. Amand, Frankie, "Climate-Driven Migration: Prioritizing Cultural Resources Threatened by Secondary Impacts of Climate Change" (2019). Electronic Theses and Dissertations. 3042.

https://digitalcommons.library.umaine.edu/etd/3042

This Open-Access Thesis is brought to you for free and open access by DigitalCommons@UMaine. It has been accepted for inclusion in Electronic Theses and Dissertations by an authorized administrator of DigitalCommons@UMaine. For more information, please contact um.library.technical.services@maine.edu. 


\title{
CLIMATE-DRIVEN MIGRATION: PRIORITIZING CULTURAL RESOURCES THREATENED BY SECONDARY IMPACTS OF CLIMATE CHANGE
}

\author{
By \\ Ani St. Amand \\ University of Southern Maine, B.A. in Geography/Anthropology \\ A THESIS \\ Submitted in Partial Fulfillment of the \\ Requirements for the Degree of \\ Master of Science \\ in Quaternary and Climate Studies
}

The Graduate School

The University of Maine

May 2019

Advisory Committee:

Alice R. Kelley, Instructor, School of Earth and Climate Sciences and Research Associate Professor, Climate Change Institute, Advisor

Daniel H. Sandweiss, Professor of Anthropology and Quaternary and Climate Studies, Cooperating Professor of Earth and Climate Sciences and Global Policy, Advisor

Christine Beitl, Assistant Professor, Department of Anthropology 


\title{
CLIMATE-DRIVEN MIGRATION: PRIORITIZING CULTURAL RESOURCES THREATENED BY SECONDARY IMPACTS OF CLIMATE CHANGE
}

\author{
By \\ Ani St. Amand \\ Thesis Advisor: Dr. Alice R. Kelley and Dr. Daniel H. Sandweiss \\ An Abstract of the Thesis Presented \\ in Partial Fulfillment of the Requirements for the \\ Degree of Master of Science \\ in Quaternary and Climate Studies \\ May 2019
}

Archaeological sites suffer increasingly destructive primary impacts of climate-driven natural hazards, including sea level rise, flooding, and erosion. Action is generally limited to mitigation and salvage of immediately threatened sites, with little attention or forethought given to secondary effects, such as destruction of interior archaeological resources by inland migration of affected populations. The United Nations predicts a growing trend in resettlement of climate-affected communities from areas where in-situ infrastructure adaptations are not economically feasible, legal, or physically possible. While adapting existing urban infrastructure (e.g., abating combined sewage overflows) is a viable option in the primary impact zone (e.g. coastal areas experiencing erosion due to sea level rise and increased storm surge), other circumstances may require new construction (e.g., water treatment plants, waste disposal) in less-developed inland areas. Resettlement and construction will thus threaten cultural sites outside the immediate zone of flooding and erosion. These archaeological sites represent important cultural and paleoenvironmental archives covering millennia of human occupation, 
including information which may help improve projections of climate change. The scientific community must develop standard methods for assessing threats to archaeological sites considering both primary and secondary effects of climate change.

Using Southern Maine as a pilot study, this thesis reports a trial methodology for integrating decadal-to-centennial climate change projections, socio-economic and demographic data, and state and federal cultural resource management regulations with satellite imagery to create a robust, user-friendly risk assessment methodology for cultural resources. This quantitative framework produces multi-scalar spatial tools to access potential archaeological resource destruction due to climate-driven population and infrastructure density increases during the period from present to 2100 . The products are multi-scalar maps at the town and parcel level that identify and prioritize threatened interior cultural resources facing destruction by secondary climate change impacts prior to large-scale migration and economic development. Use of these data will promote cultural heritage preservation and ensure compliance with federal and state legislation. Key to this research is its open-access commitment; all information used to develop this framework is freely available, and similar data may be obtained to reproduce this risk assessment nationwide. This research will help communities and states create informed mitigation plans that adhere to federal, state, and local cultural resource laws, while enabling planned economic development to proceed. 


\section{DEDICATION}

This thesis research was conducted at the University of Maine at Orono, which is built on land stolen from the Penobscot Nation. 


\section{ACKNOWLEDGEMENTS}

This project and the concept of climate-driven resettlement and threats to cultural resources was proposed by one of my advisors, Dr. Daniel H. Sandweiss. The research that followed would not have been possible without the guidance and support of both of my advisors, Dr. Alice R. Kelley and Dr. Daniel H. Sandweiss. Dr. Arthur Spiess of the Maine Historic Preservation Office offered invaluable feedback and data that were crucial to the completion of this thesis. Dr. Nathan Hamilton of the University of Southern Maine provided archaeological survey data and feedback during the formational stages of this research. Conversations with Dr. Jonathan Rubin of the University of Maine's School of Economics regarding risk assessment matrices and socioeconomic drivers ("pull factors") of migration (termed "risk factors" in this thesis) were also very helpful in the early stages of this research. Lastly, I thank Emma Wynne Hill for reading through this thesis several times and for being better at grammar - and sometimes even math - than I. 


\section{TABLE OF CONTENTS}

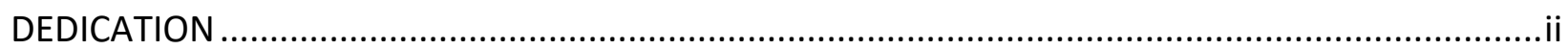

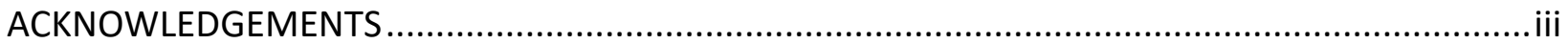

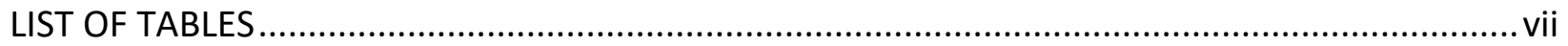

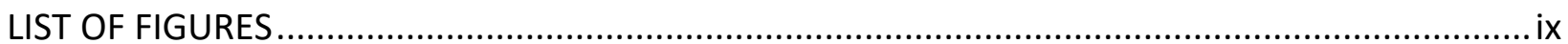

Chapter

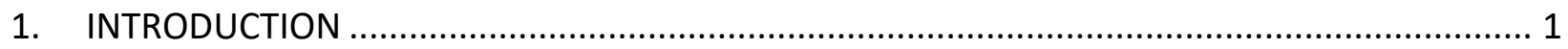

The Importance of Cultural Resources ........................................................................ 2

Secondary Threats to Archaeological Sites............................................................ 3

Archaeological Sites as Non-Renewable Resources …………………………....... 5

Stewardship of Archaeological Resources ........................................................... 6

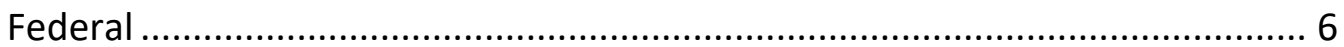

State

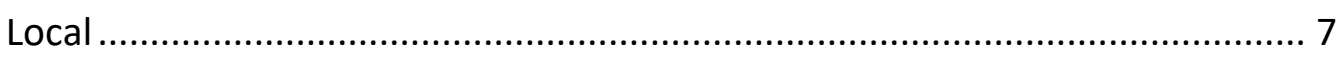

Prioritization of Most Threatened Sites........................................................... 8

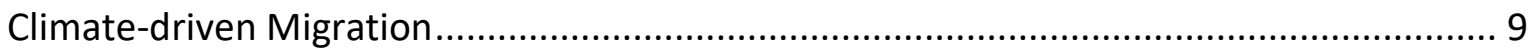

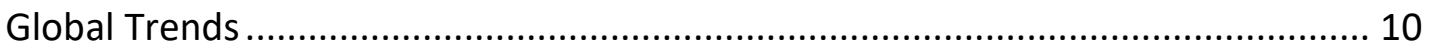

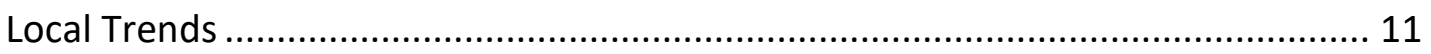

Factors Influencing Climate-driven Resettlement in Maine................................... 12

Maine Coastal Development Regulations ……………………………….... 12

Risk Assessment Versus Population Projections .................................................. 14 
Pilot Study 16

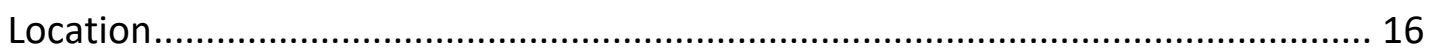

Open Access: Freely Available and Accessible Data ............................................... 18

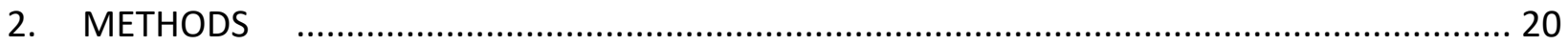

Risk Assessment Frameworks ............................................................................... 20

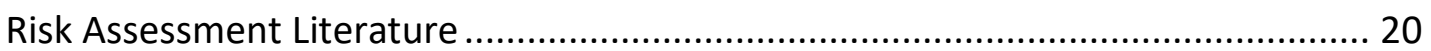

Combining Disparate Datasets in a Risk Assessment Framework ............................ 21

Risk Assessment Criteria .......................................................................... 22

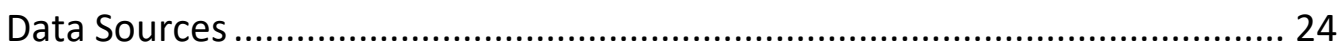

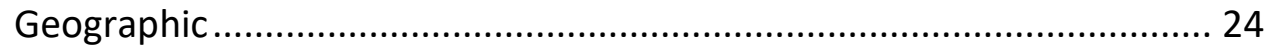

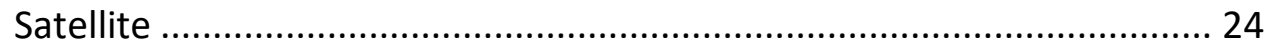

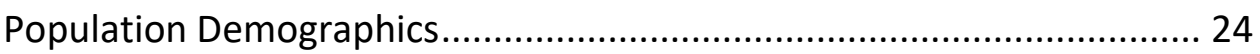

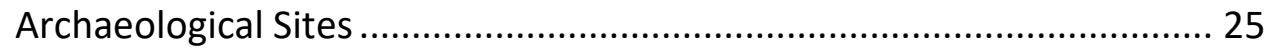

Identification of Risk Characteristics ........................................................... 25

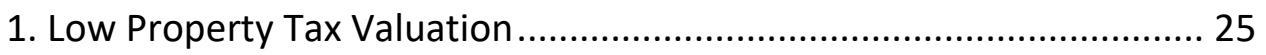

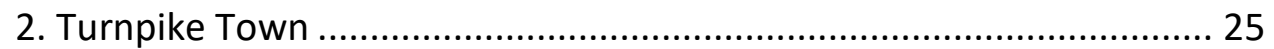

3. Rapid Population Growth................................................................... 26

4. Rapid Construction of Housing Units ................................................. 28

5. Increase in Impervious Surfaces Relative to Surrounding Towns......... 30

4. Biases in Chosen Risk Factors ……….............................................. 33 
3. RESULTS

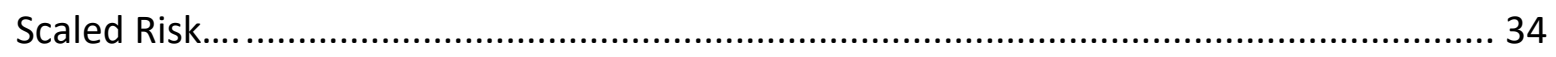

Results of the Weighted Risk Matrix....................................................................... 35

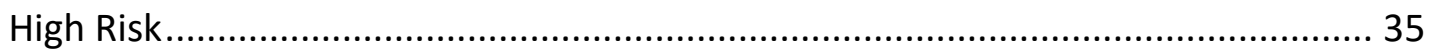

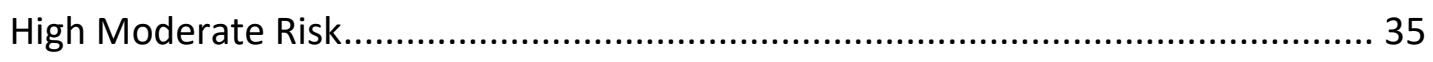

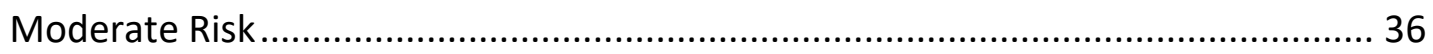

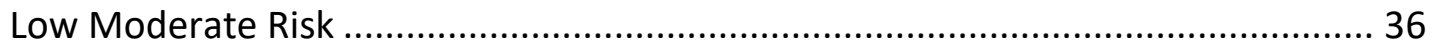

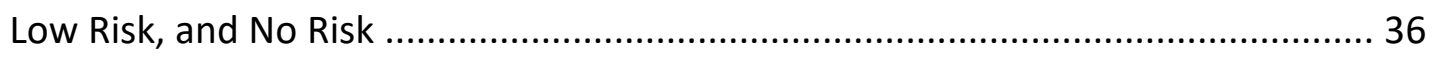

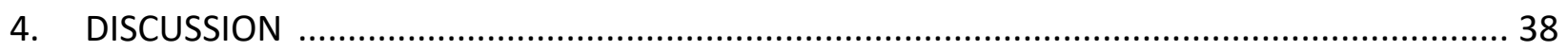

Products of the Risk Assessment Framework.............................................................. 38

Implications of Risk Assessment Scale ................................................................ 38

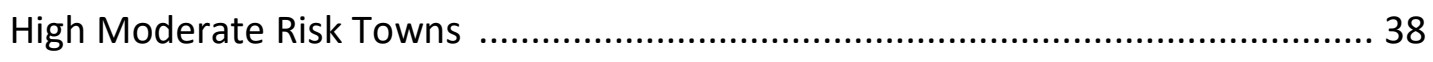

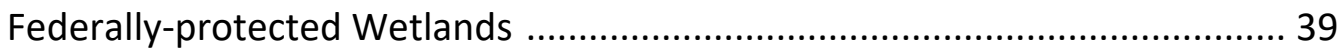

Multiple Levels of Protection ............................................................ 40

Site Location Law ........................................................................ 40

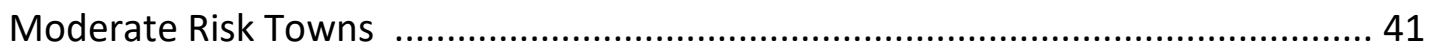

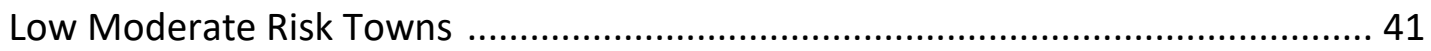

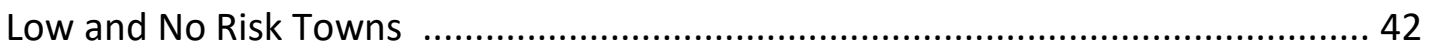

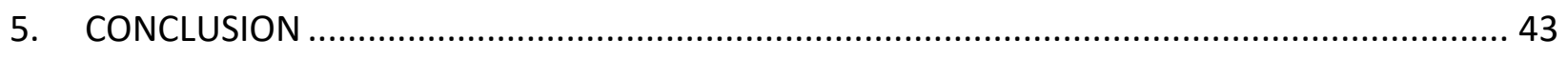

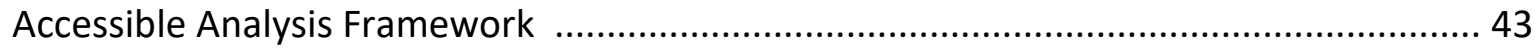

Framework may be Updated as New Data is Released ................................... 43

Use by Communities, Agencies, and Urban Planners ...................................... 43 
Next Steps

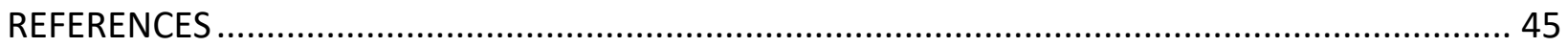

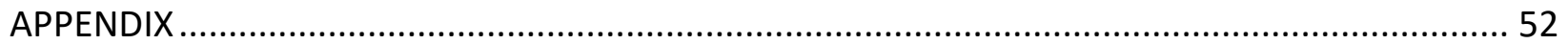

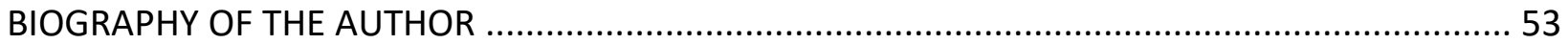




\section{LIST OF TABLES}

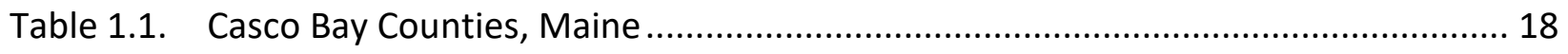

Table 2.1. Quantitative Risk Matrix Table for Casco Bay Area, Maine .................................... 23

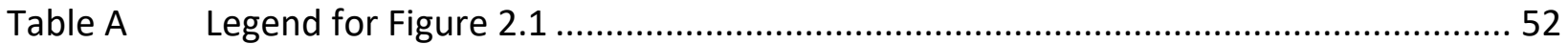




\section{LIST OF FIGURES}

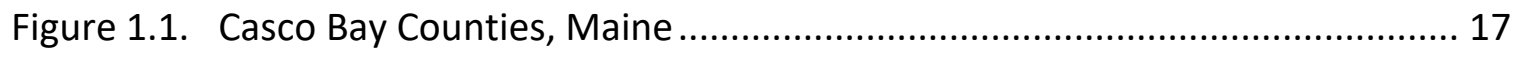

Figure 2.1. Population Growth and Housing Unit Construction in Southern Maine,

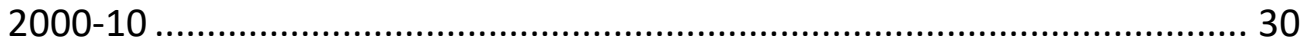

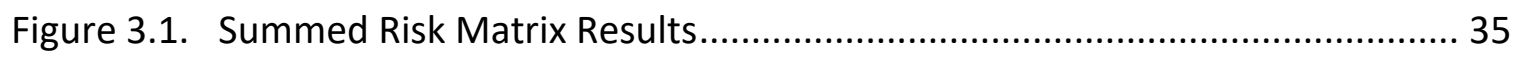




\section{CHAPTER 1}

\section{INTRODUCTION}

The severity and number of climate change threats to archaeological sites grow yearly. Anthropogenic sea level rise (SLR) and progressively more extreme weather events increasingly impact coastal areas through tidal flooding, chronic inundation, storm surge, and coastal erosion (Intergovernmental Panel on Climate Change 2014; Lentz et al. 2016; National Oceanic and Atmospheric Administration 2017; Union of Concerned Scientists 2017; Vermeer, Rahmstorf 2009). Addressing these negative impacts to people and infrastructure will be costly. Communities will face difficult choices as chronic flooding events and erosion increase. Taxpayer-funded public infrastructure maintenance and adaptation already stress economies and federal services in the direct impact zone. The Federal Emergency Management Agency (FEMA)'s National Flood Insurance Program (NFIP) is underprepared and overburdened in the face of unpredictable and increasingly extreme weather events (Katz 2017). Not only has this resulted in insolvency, but the systematic underestimation of cost and risk encourages development in flood-prone coastal and low-lying areas (Katz 2017). However, the problem is more complex. Over the course of this century, displacement of people due to climate change will increase (Intergovernmental Panel on Climate Change 2014; The United Nations Migration Agency 2017). While climate-driven population resettlement poses obvious socio-economic challenges for individuals and communities, migration will also impact landscapes in profound ways. The landward migration of coastal populations is a secondary impact of climate change that threatens cultural resources outside of the immediate zone of direct impact, a concern that has not been given appropriate attention (Anderson et al. 2017). I develop the theoretical 
concept of 'secondary impacts' of climate change in more detail below. This concept is foundational to this research and more broadly, it is important for the field of climate and cultural heritage research. Given the threat that secondary impacts of climate change pose to cultural resources, this risk assessment tool is valuable because it identifies which towns are most likely to experience increases in population density, housing units, or associated infrastructure due to climate-driven migration, which increase threats to archaeological sites and our cultural heritage archive.

\section{The Importance of Cultural Resources}

Cultural resources include the remains of past human activity, both indigenous and colonial. These resources include historic buildings, artifacts, human and faunal remains, hunting and occupation sites, as well as earthworks and modified landscapes. These important sites collectively archive thousands of years of human occupation constituting the human history of a region. There are many types of archaeological sites, and they are culturally important to diverse groups of people for many reasons. Native and Indigenous peoples with ties to the landscape and to cultural and burial items recovered in excavations have strong and inherent connections to archaeological sites and the material collections they hold. Local and state communities also benefit from learning the complex and shared histories of these sites in their contextual landscapes, as well as the evidence of the history with which they identify. In addition to serving as indicators of human activity, archaeological sites preserve evidence of dynamic changes in the landscape through time, such as gradual sea level rise or changes in regional populations of flora and fauna. Archaeological sites also contain unique information that helps us understand past climatic and environmental change (Kaufman et al. 2018; 
Sandweiss, Kelley 2012). These paleoclimatic and paleoenvironmental proxies are stratigraphically associated with human behavior on interannual, decadal, and centennial timescales relevant to human lifespans.

This research addresses those sites that are recorded within the Maine Historic Preservation Commission database and surveys provided by Nathan Hamilton of the University of Southern Maine. These sites are those located in highly visible locations, such as along the coast, or encountered in the course of academic or legally required surveys. Large-scale development or construction funded with state or federal monies include a mandate for archaeological survey. The large number of sites associated noted along waterways is the result of federally and state mandated surveys associated with hydroelectric dam relicensing projects. There are likely many unknown archaeological sites on both private and public land that do not exist within available records. For this reason, archaeological site locations provided by the Maine Historic Preservation Commission (MHPC) and Nathan Hamilton are biased by what appears to be a general absence of sites from interior regions but is likely because there are fewer construction projects in less-developed, less-populated regions. Kellogg's archaeological site predictive model (Kellogg, 1987), which identifies factors that may have influenced settlement patterning (e.g. distance to water or slope of land) and thus may be used to predict site locations, was developed for a coastal region of the state. However, similar concepts may be applied to approximate site density or settlement patterning in interior regions.

\section{Secondary Threats to Archaeological Sites}

Identifying cultural resources threatened by the primary impacts of climate change (sea level rise, flooding, and erosion) under various scenarios is a process challenged by uncertainty 
(IPCC, 2014; Lentz et al. 2016). However, this effort is enhanced by the increase in publiclyavailable data and user-friendly models in online interfaces, including projections at the local level. It is straightforward to extend these models to determine where archaeological sites are at risk of primary destruction by climate change, but it is far more complex to consider the potential destruction of cultural resources in formerly undeveloped interior regions due to climate-driven resettlement (a secondary impact of climate change). The concept of secondary impacts of climate change, including impacts of climate-driven migration and development on cultural resources, does not exist in the literature, but is a crucial component of any future conversations about climate change and cultural heritage,

This research uses the wealth of archaeological resources in southern Maine as a case study of what may be threatened by climate-driven migration, while developing a framework that can be used to assess risks posed to sites in similar coastal regions. While this pilot study focuses on pre-European, Native American sites, there are many significant Colonial EuroAmerican historic archaeological sites in the project area that will suffer the same effects. Due to Maine's low population density, many Native American archaeological sites remain intact because they are located in relatively undeveloped areas. However, increasing future resettlement will result in housing and infrastructure pressures in these previously low-density areas. Archaeological sites will face damage and destruction due to ground disturbance associated with the construction of buildings, roads, and electrical and energy corridors, as well as direct human interference such as foot traffic and artifact collection. Economically-driven development of rural regions is already affecting archaeological sites; this trend will likely only be exacerbated by climate-driven relocation. 
Protection of these nonrenewable resources requires accessible records of known sites, as well as strategies for the identification of new, unreported sites. Due to limited time and funding, and to the realities of primary and secondary forms of climate-driven destruction of archaeological sites, developing systemic frameworks for site prioritization is crucial.

\section{Archaeological Sites as Non-Renewable Resources}

While the Maine Historic Preservation Commission works to ensure that significant cultural resources are legally and physically protected, sometimes it is not possible to avoid site destruction. In these circumstances, mandated archaeological data recovery via surveys and/or excavation takes place, accompanied by a thoroughly documented report about the site's extent, context, and contents. If room and funds allow, collected materials are stored in a museum or other repository for future restudy. The downside of this type of mitigation of site destruction is that the archaeological site (a non-renewable resource) is still ultimately destroyed. While current knowledge is advanced somewhat by this practice, only a sample of the archaeological information is retained for future research, and we must rely on the limitations of current best practices for data collection. Screen size is a prominent issue impacting the presence or absence of some cultural, environmental, and climatic proxies such as pollen or small fish bones, as larger screen sizes fail to recover these small items. Soil samples are also not obtained in systematic manners from all excavations, dramatically reducing the wealth of information needed to reconstruct soil stratigraphies or to interpret cultural horizons. Future advances in technology will not be utilized to enrich our understanding of the site or its unexcavated contents because both those contents and their contexts will no longer exist. For example, advances in photogrammetry and site survey, which have become 
more widely used over the last decade, cannot be employed to map extent or topography at sites which have been destroyed by primary or secondary impacts of climate change.

Sometimes archaeological sites are destroyed without the opportunity to survey their extent or collect information. These trends are not restricted to southern Maine. Cultural resources throughout North America (and the world) are facing similar increased pressures due to climate change and development.

\section{Stewardship of Archaeological Resources}

Federal. Federal legislation, in addition to local and state law, protects cultural resources. At the federal level, the Archaeological and Historic Preservation Act requires Federal agencies to ensure "...the preservation of historical and archeological data which might otherwise be irreparably lost or destroyed as the result of... any alteration of the terrain caused as a result of any Federal construction project or federally licensed activity or program" (Center for Regulatory Effectiveness 2007). Pending projects of this nature, and per the National Historic Preservation Act (NHPA), federal agencies and all parties involved (state, town, or landowner) that plan to use federal funds or that need a federal permit must consult with the State Historic Preservation Office in order to avoid "adverse effect" to significant archaeological sites (Center

for Regulatory Effectiveness 2007). An example of a required federal permit is an Army Corps of Engineers permit for dock construction along tidewater. Federally funded projects requiring archaeological survey include Maine Department of Transportation roads and bridges construction and repair, and partially federally funded projects including cell phone towers and water and sewer projects. 
State. At the state level, the NHPA tasks U.S. states with defining what constitutes "significant" or "National Register eligible" archaeological sites. Maine’s Site Location Law requires state level review of development proposing 7 or more acres of impervious surfaces (buildings and parking lots), or any subdivision greater than 20 acres (Maine Department of Environmental Protection 2018). The Site Location Law greatly reduces the risk of inadvertent site damage because it requires the integration of a predictive model for Native American sites (personal communication, Arthur Spiess). Survey is required when construction will fall within an area where there is a reasonable likelihood of archaeological site presence (personal communication, Arthur Spiess). Many other states lack similar Site Location Laws. As a result, threat identification frameworks such as the one developed in this thesis could be increasingly useful in other parts of the country.

Local. At the local level, towns may enact ordinances protecting archaeological sites. Some Maine municipalities have future growth management plans that include archaeological sites (Town of Scarborough 2018; Town of South Portland 2017). These plans are the primary source of consultations with the MHPC for local building permit applications. Regions of the country that lack growth management plans, or whose plans fail to include archaeological sites, have higher need for risk identification frameworks. Because of the number of laws protecting archaeological resources and the mitigation processes required for federally-funded or permitted projects to proceed, it is within the interest of towns ${ }^{1}$ and states to identify threats to archaeological resources in advance of large-scale migration and development efforts.

\footnotetext{
${ }^{1}$ Maine towns are functional units of local government, resembling townships in most of the rest of the country. Towns in Southern Maine contain rural territory as well as population centers. Maine's 433 towns and 36 plantations cover the entire land area of the state (U.S. Census Bureau 1994).
} 


\section{Prioritization of Most Threatened Sites}

In the context of rising sea levels and increases in storm surge, flooding, and erosion, as well as climate-driven resettlement, construction, and infrastructure adaptation projects, it has become clear that prioritizing sites at the highest risk of destruction is an extremely important component of cultural resource stewardship (Heilen et al. 2018; Howard 2013; Reeder-Myers 2015). A recent publication in the journal Conservation and Management of Archaeological Sites states that "Efforts are needed to identify, record, and study resources that will be affected" (Heilen et al. 2018). There is growing recognition that stewardship policies must use site prioritization frameworks to assess which sites are at greatest risk of destruction due to climatic or anthropogenic forces. The Committee on Climate Change Strategies and Archaeological Resources of the Society for American Archaeology, the largest organization of archaeologists in the Americas, continues to wrestle with this issue (Society for American Archaeology, 2019). The National Park Service (NPS) has also recently identified prioritization as a key component of cultural resource management as they move forward to address climate change impacts in the parks. The director of the NPS recently released policy memo 14-02, titled "Climate Change and the Stewardship of Cultural Resources", calling for prioritization to become a part of stewardship (Rockman 2015). Marcy Rockman, former NPS Climate Change Adaptation Coordinator for Cultural Resources, notes that the federal government should work to spearhead policies regarding inventorying and prioritization of "areas that are most at risk from broad geographic climate impacts" (Rockman 2015). The lack of support for cultural resource management in an era of increasing climate change is a real 
problem that is not being adequately addressed or funded. The framework presented in this study represents a free and accessible step towards meeting goals of site prioritization for increasing the stewardship of cultural resources. It does so by answering the question "what puts a town at risk for migration?", and then ranks towns by degree of risk to known and predicted archaeological site locations.

\section{Climate-driven Migration}

Climate-driven coastal resettlement differs from migration motivated by other forces (political, demographic, environmental) because populations affected by SLR (a consequence of climate change) have few options other than relocation (Döös 1997). More than other types of migration, climate-driven migration necessitates effective and proactive planning on the part of government and communities. Without such planning, rapid construction of residential, commercial, and industrial buildings, as well as urban infrastructure associated with population growth (roads, energy corridors, parking lots, and waste management systems) often results in poorly managed, uncoordinated, and inefficient development (Savage, Lapping 2003). While resettlement and climate-driven development occur, it is crucial that municipalities and states adhere to federal, state, and local regulations and laws that are enforced to protect cultural resources from inadvertent destruction. Being proactive about adhering to these laws can ensure that planned economic development can proceed without costly or time-consuming interruptions to construction for cultural resource management surveys or investigations which would have been avoided with proper planning (for more discussion, refer back to Stewardship of Archaeological Resources, Chapter 1). 
In addition to the economic burdens of maintenance and adaptation of coastal

infrastructure, other obstacles will limit coastal occupation in the face of sea level rise. I discuss these below and have tried to integrate these factors (e.g. physical or legal restrictions) into this analysis.

Predicting population migration is difficult and predicting climate-driven migration is more so (Hauer 2017; Moser 2005). We cannot simply project past trends to understand a changing human dynamic such as resettlement in response to climate change. This underscores the need to develop a risk assessment framework to identify areas that may be suitable or preferential for climate migrants, based on a number of contextualized factors (see chapter 2 for discussion).

\section{Global Trends}

Globally, the economic cost of flooding and weather-related damage has increased since the 1970's, attributed in part to the increase of coastal populations and infrastructure, a trend that has not changed despite an increase in weather and SLR-related disasters (Intergovernmental Panel on Climate Change 2014; Dailey et al. 2012). In 2008, 54.2\% of Maine's population lived in a coastal county, a figure that has seen consistent decadal increases (totaling 8.8\%) since 1960 (Wilson, Fischetti 2010). Though community-based adaptation (mitigation in place) is still a priority, relocation is an increasing global trend, as " $[c]$ limate change is expected to trigger growing population movements within and across borders as a result of such factors as increasing intensity of extreme weather events, sea-level rise and acceleration of environmental degradation" (The United Nations Migration Agency 2017). The United States Department of Housing and Urban Development (HUD) designated \$48.3 million 
to assist the Band of Biloxi-Chitimacha-Choctaw tribe to relocate off the Isle de Jean Charles, Louisiana, 98\% of which has disappeared under rising waters since 1955 (U.S. Department of Housing and Urban Development 2016). Kivalina, Alaska is another community facing diminishing land and potential relocation. Costly U.S. Army Corp adaptation projects over the past several decades have failed to protect Kivalina from severe erosion (U.S. Climate Resilience Toolkit 2017). Changing climate has caused a decrease in sea ice on this barrier island, which previously prevented major erosion events during cold weather storms (NANA Regional Corporation, Inc. 2016). In the absence of sea ice, cold weather storms can destroy up to 30 meters of shoreline in a single event (Alaska Native Tribal Health Consortium 2011). HUD has recently warned that the harmful effects of climatic change on communities are only expected to increase and intensify (U.S. Department of Housing and Urban Development 2014).

\section{Local Trends}

While SLR projections include a wide range of scenarios for Portland, Maine by the year 2100 ( 0.5 to 3.3 meters, with an average of 1.8 meters) (NOAA Office for Coastal Management 2015), coastal southern Maine is already experiencing primary impacts of climate change (Dickson 2018; Federal Emergency Management Agency 2014; Greater Portland Council of Governments 2013). Coastline retreat, bluff erosion, increased storm severity, and chronic "nuisance" flooding have been negatively impacting human populations and infrastructure here for several decades. Nearly 1 billion dollars are estimated in projected flood-related losses by 2100 (Federal Emergency Management Agency 2014). 


\section{Factors Influencing Climate-driven Resettlement in Maine}

Coastal regions in Southern Maine (pilot study area) and throughout North America are clearly experiencing primary impacts of climate change. In the Casco Bay area, Scarborough, South Portland, and Phippsburg coastlines are retreating due to impacts of rising sea levels and erosion, while the Portland peninsula experiences ever-more frequent inundation and chronic flooding events (Dickson and Sidell 2003). Also known as nuisance flooding, chronic flooding not only impacts buildings but also road, electrical, and gas services, and can cause issues with combined sewage overflow systems in cities, leading to extensive adaptation projects. Sea level rise, combined with the increasing intensity and occurrence of extreme weather events means that formerly 100-year storms have a higher chance of occurring on an annual basis (Tebaldi et al. 2012). It is likely that significant erosion of beach dunes, such as that caused in Phippsburg by storm surge related to a four-day northeaster, will occur more often (Slovinsky 2005). Frontal dune overwash will also become more common, reshaping ecosystems and impacting the way humans live on the coast (Slovinsky 2005). In Saco Bay, just south of Casco Bay, 36 developed lots have been lost to chronic flooding and storm-related coastal erosion over the past century (Slovinsky 2005). At this location, erosion at a rate of 2-3 feet of coastline per year is exacerbated by a jetty, which blocks the influx of natural sediment that formerly replenished beaches in the area (Slovinsky 2005).

Maine Coastal Development Regulations. Since the late 1980's, Maine's coastal hazard area development regulations have considered anthropogenically-induced SLR, influencing coastal urban policies (Moser 2005). In southern Maine, new construction on shorelines is not permitted if the property is predicted to experience destructive erosion under a conservative 
SLR scenario of 0.6 meters of rise by 2100 , and existing seawalls are not considered sufficient to guarantee site stability (Maine Department of Environmental Protection 2014). While rip-rap and other similar erosion control projects may take place pending reviews, new seawall construction is not permitted, and reconstruction of damaged seawalls is limited, as is the rebuilding of a structure that has experienced $>50 \%$ damage of its appraised value (Maine Department of Environmental Protection 2014; Moser 2005).

Maine still lacks comprehensive adaptation or retreat management plans, even as climate change impacts on coastal towns continue to increase. The state's 1989 Growth Management Act, enacted to encourage comprehensive development plans at the community and town level, was developed to "encourage orderly growth and development", to "develop an efficient system of public facilities and services to accommodate anticipated growth and economic development", and to protect natural and marine resources, as well as historic and archaeological resources (Maine State Planning Office 2006). Though the document addresses state foci, regional development plans, and local planning for future development, it does not mention climate change - nor does the evaluation published in 2006 by the state Planning Office (Maine State Planning Office 2006). While some coastal towns have adopted comprehensive development plans that explicitly address sea level rise, flooding, and erosion (Portland, South Portland, and Scarborough, for example), a push for planning at the state level does not exist.

This problem was exacerbated in 2012 when then Governor Paul LePage abolished the State Planning Office, a department that was responsible for sustainable development, for analyzing economic and conservation options, and for assisting towns in developing and 
assessing socio-economic forecasts (Digital Maine 2018). The Muskie School of Public Service, which has historically worked on issues of climate-driven resettlement and related development pressures, lost faculty in 2014 when the University of Southern Maine was forced to make large budget cuts (Schauffler 2017). Because of all these shifts over the past decade, planning for climate change in Maine occurs at the municipal level, rather than systematically at the state level. Some state programs, such as the Maine Geological Survey and the Maine Department of Environmental Protection, do recognize sea level rise, flooding, and coastal erosion as pressing issues, and produce guidelines and regulations for construction, adaptation, and mitigation under a climate change framework (Dickson and Sidell 2003; Slovinsky 2005; Moser 2005; Maine Department of Environmental Protection 2014).

While these are a start, the state needs stronger measures to address climate change, as impacts are already occurring. Since 2005 , waterfront properties in Maine coastal towns have lost $\$ 70$ million in value due to tidal flooding related to SLR (Russell and Miller, 2019). Biddeford, Scarborough, and Saco rank as some of the towns experiencing highest losses in property values, with $\$ 3.7, \$ 2.7$, and $\$ 2.2$ million dollars in declines, respectively (Russell and Miller, 2019). In Camp Ellis, a seaside community in Saco, increases in storm surge reach and erosion have cost the city more than $\$ 300,000$ annually for the past decade. This money has been spent on mitigation efforts to save eroding shorelines and damaged roads, and homes now stand right at the ocean's edge (Graham, 2018).

\section{Risk Assessment Versus Population Projections}

Given projections of increasing SLR-induced storm surge and coastal erosion, as well as current restrictions on construction of buildings and seawalls in coastal Maine, it is likely that 
populations in the immediate impact zones will relocate by the end of the century. It is clear that traditional population growth estimates, whether direct or indirect, fail to account for alterations in human behavior driven by changing environments at the town, county, or state level. A recent study by Hauer (2017) models future climate-driven migration, while accounting for populations that may adapt to SLR. That study assesses change over the next century on the U.S. east coast, and while useful, it has limitations because its projections are ultimately based on past census trends, a problem that Hauer recognizes (Hauer 2017). Not only are there uncertainties in climate predictions for this century, but also unpredictability in the human behavioral response to unfamiliar climate scenarios (Aerts 2017). According to the UN, "[t]he links between climate change and migration ... are usually far from simple and direct" (The UN Migration Agency 2017). Despite the difficulties, developing user-friendly frameworks for identifying potential threats to cultural resources that use open source and nationally-available data will increase accessibility and lay the groundwork for more in-depth studies.

In light of our understanding that climatic pressures will continue to modify human behavior, it is inappropriate to ground future simulations exclusively on past trends. To address this concern, I use a summed risk assessment matrix (see Chapter 2) to understand potential population movement within the context of threats to cultural resources. While used in the field of economics, and more often in decision-making contexts such as industry, this method can also be used to assess development threats across the landscape because this process represents a similar ranking of threats (Cox 2008; Henselwood and Phillips 2006; Li et al. 2002). The framework I develop here identifies the counties and towns that have a higher likelihood of experiencing increases in population and/or housing density in the future, allowing examination 
of climate-driven threats to cultural resources without relying only on past trends and assumptions about future migration. The product of this risk assessment is a multi-scalar spatial tool that indicates where cultural resources may be negatively impacted or destroyed due to climate-driven migration. This framework does not produce a mandate (to excavate more, to prioritize one site over another), but instead offers information at the town level about where climate-driven migration is likely to threaten archaeological sites. This information is important to various stakeholders and the product (level of threat of destruction of sites based on location and on 'risk factors' discussed in chapter 2) may be interpreted differently by different parties. The information provided by the framework may, of course, be used to prioritize sites for mitigation (see Chapter 2, section on Risk Assessment Literature).

\section{Pilot Study}

\section{Location}

I selected the Casco Bay region in southern Maine for this pilot study because it has both coastal and interior population centers, the later of which are likely to experience increases in climate-driven migration. This region has mixed urban and rural areas, as well as industrial and agricultural zoned areas in both the interior and the coast. There are also concentrations of residences (e.g. cities as well as beach front homes) that are already experiencing primary impacts of climate change, an important driver of this form of migration. 
Figure 1.1: Casco Bay Counties, Maine. Internal divisions within counties are towns (See Table A in the Appendix for a map legend with town names).

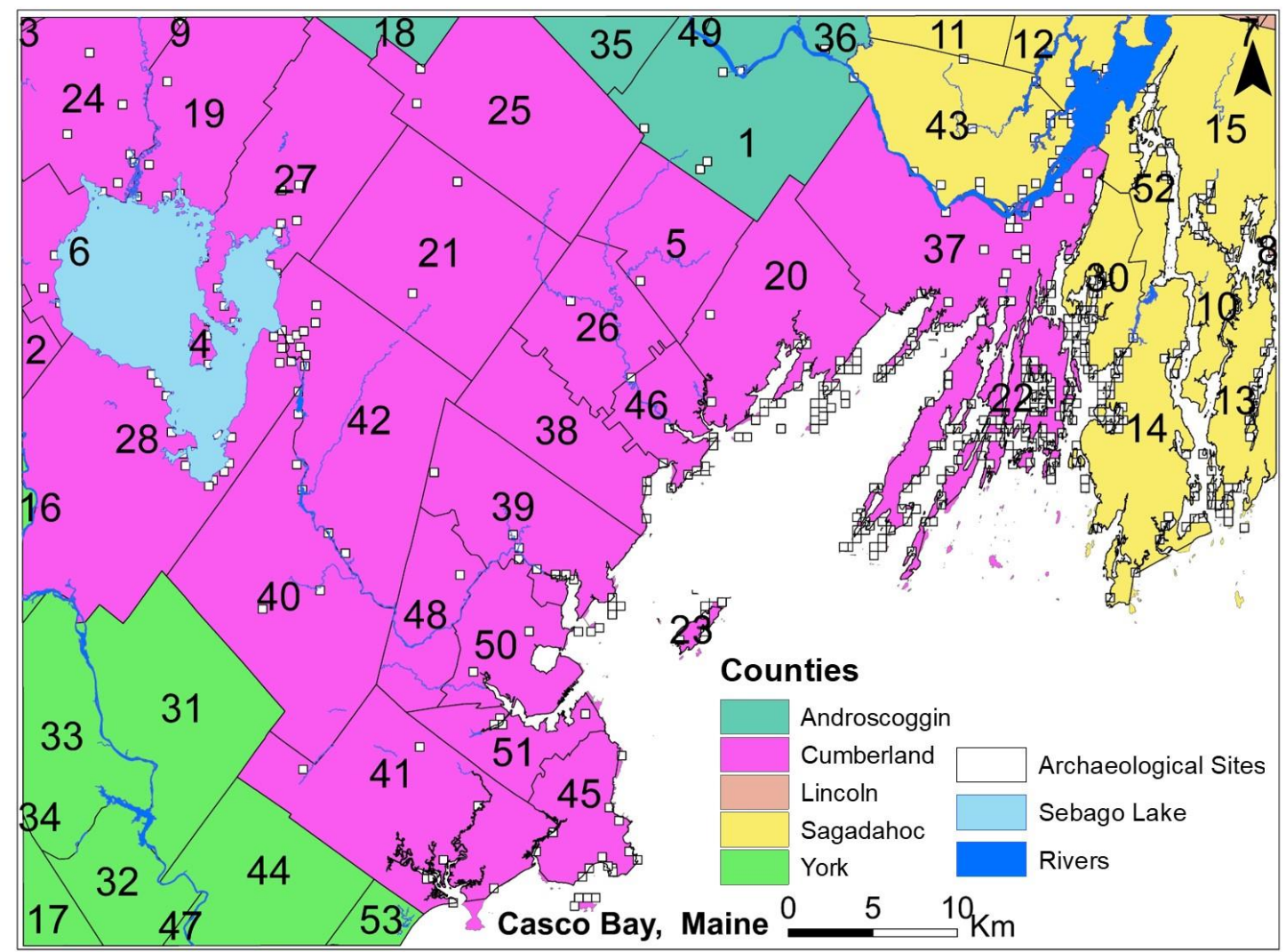

This pilot study includes the 52 towns of Durham, Baldwin, Bridgton, Frye Island,

Pownal, Sebago, Dresden, Westport, Arrowsic, Bowdoin, Bowdoinham, Georgetown,

Phippsburg, Woolwich, Limington, Lyman, Poland, Casco, Freeport, Gray, Harpswell, Long

Island, Naples, New Gloucester, North Yarmouth, Raymond, Standish, Wiscasset, West Bath, Buxton, Dayton, Hollis, Waterboro, Auburn, Lisbon, Brunswick, Cumberland, Falmouth, Gorham, Scarborough, Windham, Topsham, Saco, Cape Elizabeth, Yarmouth, Biddeford, Westbrook, Lewiston, Portland, South Portland, Bath, and Old Orchard Beach. See Table A in the Appendix for a map legend with town names. These are distributed across Androscoggin, Cumberland, Lincoln, Sagadahoc, and York counties, totaling $2810 \mathrm{~km}^{2}$. 
These five counties have a combined 2017 population estimate of 695,985 , according to the U.S. Census Bureau, which conducts decadal surveys (the last one was in 2010) (U.S. Census Bureau 2012). In 2010, 814,819 of Maine's population (1,328,361; 61.3\%) lived in rural areas, defined as "all areas outside Census places with 2,500 or more people". The remaining 513,542 people (38.7\%) lived in urban areas (United States Department of Agriculture, n.d.).

Table 1.1: Casco Bay Area, Maine Counties and Demographic Data (U.S. Census Bureau 2012)

\begin{tabular}{|c|c|c|c|}
\hline County & Land area in square miles & Population & Population density \\
\hline Androscoggin & 467.93 & 107,651 & 230.2 \\
\hline Cumberland & 835.24 & 292,500 & 337.2 \\
\hline Lincoln & 455.8 & 34,204 & 275.6 \\
\hline Oxford & $2,076.8$ & 57,439 & 427.8 \\
\hline York & 990.71 & 204,191 & 199.0 \\
\hline
\end{tabular}

\section{Open Access: Freely Available and Accessible Data}

The significance of this risk assessment framework is that it provides a rapid method for identifying threats to cultural resources at the town level. Importantly, all data to be incorporated into this framework by users come from open access sources. This means that they are free and available. This systematic method can be used by anyone with basic GIS skills to prioritize archaeological sites facing destruction. While ArcMap, a proprietary software, was used in some stages of this analysis, any free GIS software (e.g. Grass) may be used with equal effectiveness.

For this pilot study: MHPC provided an archaeological site database with precise location information. Nathan Hamilton of the University of Southern Maine offered additional survey data which were digitized and added to this database. An open source equivalent of 
these data is provided by the Digital Index of North American Archaeology (DINAA), with $0.5 \mathrm{~km}$ generalized site locations rather than exact site locations as used (but not displayed) in this study (Anderson et al. 2017). This level of spatial generalization should not impact the end product of the framework. Local sea level, storm surge, and flooding records and hydrologic connectivity data were also available for this region. See Chapter 2 "Data Sources" on page 24 for specific source references for these and other data obtained and used in this research. 


\section{CHAPTER 2}

\section{METHODS}

\section{$\underline{\text { Risk Assessment Frameworks }}$}

\section{Risk Assessment Literature}

Summed risk assessment matrices are tables that allow analysis of risk of several categories across a subject group of interest. Total risk scores are tallied, and subject risk is relatively qualified across the group, enabling ranking of "highest" to "lowest" risk based on the risk criteria. Ranked outputs allow comparison that can be integrated into risk assessments where multiple factors must be considered. Risk assessment matrices are a strategy to help with decision-making when it is necessary to develop a systematic method of comparison of risks or threats. These assessments are also used to guide resource allocation when funds and/or time are limited, and is employed by regulatory agencies, industries, and a wide range of organizations to establish priorities in decision-making contexts (Cox 2008). In the fields of economics and industry, examples include identifying and prioritizing risks during maritime shipping and pipeline construction (Henselwood and Phillips 2006; Li et al. 2002). In the case of archaeological sites, funding and time provide two constraints on the number of threatened archaeological sites that can be addressed annually. Thus, using a risk assessment matrix to identify towns most likely to experience climate-driven resettlement (and thus where archaeological sites may be threatened by secondary impacts of climate change) can help prioritize those sites that are most threatened.

Within the field of cultural resource management, prioritization of archaeological sites most at risk is not common practice, despite calls for the integration of these methods into 
stewardship and management plans (see Chapter 1). Most common are assessments of threats of primary climate impacts on archaeological sites, such as sea level rise, created using climate projections and mapped locations of known archaeological sites (Maio et al. 2012;

Murdukhayeva et al. 2013; Wand 2015). In some regions, researchers have used frameworks much like the risk assessment matrix to identify and rank threatened sites. Reeder-Myers uses a vulnerability assessment framework using a summed equation rather than a risk matrix to quickly assess archaeological site vulnerability to primary climate change impacts. Her vulnerability index equation unequally weights her risk factors, however, risk assessment equations and matrices are very similar approaches to creating scaled products of risk (ReederMyers, L. A. 2015).

Unlike Reeder-Myers approach, this pilot study uses equal weights applied to all five categories of risk factors because this framework was designed to be applicable to coastal areas along the eastern seaboard of the United States. It is not prudent to assign differently weighted criteria to variables for a pilot study in Maine and then apply this framework to another state where one criterion may not carry the same level of threat. However, this framework may be modified, and risk factors may be assigned different importance, or weight, in the final summed risk matrix by adjusting the values of ' 0 ' and ' 1 ' to include higher numbers or fractions. The flexibility of the framework developed in this research may fill a gap in archaeological resource management where site prioritization methods are unfortunately scarce or non-existent.

\section{Combining Disparate Datasets in a Risk Assessment Framework}

I used a risk matrix to develop a risk scale to assess threats to archaeological sites due to climate-driven migration. This risk matrix is composed of factors that make a town appealing for 
relocation or that pose threats to cultural resources. Some characteristics are general, such as low property taxes (Maine Revenue Services 2015). Others are region-specific, and were identified from recent socio-demographic records, such as federal census data (U.S. Census Bureau 2016; Mackun and Wilson 2011; Mazur and Wilson 2011), selected state demographic studies (Boyle et al. 2006; Dailey et al. 2012), and socio-economic literature (Boyle et al. 2006; Katz 2017; White 2006). Recent demographic trends such as migration to towns with direct interstate access ("turnpike towns") occurring with increasing frequency is an example of region-specific criteria. Remotely-sensed above average increases in impervious surfaces, a method of tracking development trends, constitutes another criterion (Xian et al. 2011).

Risk Assessment Criteria. The following criteria were employed to evaluate threats to cultural resources within each town:

1. Low property taxes

2. “Turnpike town" (Dailey et al. 2012)

3. Rapid increase in population density over previous decade

4. Rapid construction of housing units over previous decade

5. Increase in impervious surfaces over time relative to surrounding towns Criteria were equally weighted (1 point each) and were summed. Risk was subsequently assigned to each town on a scale of $0-5$. 
Table 2.1: Quantitative Risk Matrix Table for Casco Bay Area, Maine ( $n=52$, see Figure 1.1)

\begin{tabular}{|c|c|c|c|c|c|c|}
\hline Town name & $\begin{array}{l}\text { 1. Low } \\
\text { property tax }\end{array}$ & $\begin{array}{l}\text { 2. Turnpike } \\
\text { town }\end{array}$ & $\begin{array}{l}\text { 3. Population } \\
\text { increase }\end{array}$ & $\begin{array}{l}\text { 4. Housing } \\
\text { unit increase }\end{array}$ & $\begin{array}{c}\text { 5. Increase in } \\
\text { impervious } \\
\text { surfaces }\end{array}$ & $\begin{array}{c}\text { Total risk } \\
\text { score }\end{array}$ \\
\hline Durham & 1 & 0 & 0 & 1 & 0 & 2 \\
\hline Baldwin & 1 & 0 & 0 & 0 & 0 & 1 \\
\hline Bridgton & 0 & 0 & 0 & 1 & 0 & 1 \\
\hline Frye Island & 1 & 0 & 0 & 0 & 0 & 1 \\
\hline Pownal & 1 & 0 & 0 & 0 & 0 & 1 \\
\hline Sebago & 1 & 0 & 0 & 0 & 0 & 1 \\
\hline Dresden & 1 & 0 & 0 & 0 & 0 & 1 \\
\hline Westport & 1 & 0 & 0 & 0 & 0 & 1 \\
\hline Arrowsic & 1 & 0 & 0 & 0 & 0 & 1 \\
\hline Bowdoin & 1 & 1 & 0 & 0 & 0 & 2 \\
\hline Bowdoinham & 1 & 1 & 0 & 0 & 0 & 2 \\
\hline Georgetown & 1 & 0 & 0 & 0 & 0 & 1 \\
\hline Phippsburg & 1 & 0 & 0 & 0 & 0 & 1 \\
\hline Woolwich & 1 & 0 & 0 & 0 & 0 & 1 \\
\hline Limington & 1 & 0 & 0 & 0 & 0 & 1 \\
\hline Lyman & 1 & 0 & 0 & 0 & 0 & 1 \\
\hline Poland & 1 & 0 & 0 & 0 & 0 & 1 \\
\hline Casco & 1 & 0 & 0 & 1 & 0 & 2 \\
\hline Freeport & 0 & 1 & 0 & 0 & 0 & 1 \\
\hline Gray & 0 & 1 & 0 & 0 & 0 & 1 \\
\hline Harpswell & 0 & 0 & 0 & 0 & 0 & 0 \\
\hline Long Island & 1 & 0 & 0 & 0 & 0 & 1 \\
\hline Naples & 1 & 0 & 0 & 0 & 0 & 1 \\
\hline New Gloucester & 1 & 1 & 0 & 0 & 0 & 2 \\
\hline North Yarmouth & 1 & 0 & 0 & 0 & 0 & 1 \\
\hline Raymond & 0 & 0 & 0 & 0 & 0 & 0 \\
\hline Standish & 0 & 0 & 0 & 0 & 0 & 0 \\
\hline Wiscasset & 1 & 0 & 0 & 0 & 0 & 1 \\
\hline West Bath & 1 & 0 & 0 & 0 & 0 & 1 \\
\hline Buxton & 1 & 0 & 0 & 0 & 0 & 1 \\
\hline Dayton & 1 & 0 & 0 & 0 & 0 & 1 \\
\hline Hollis & 1 & 0 & 0 & 0 & 0 & 1 \\
\hline Waterboro & 1 & 0 & 1 & 0 & 0 & 2 \\
\hline Auburn & 0 & 0 & 0 & 0 & 0 & 0 \\
\hline Lisbon & 1 & 0 & 0 & 0 & 0 & 1 \\
\hline Brunswick & 0 & 1 & 0 & 0 & 1 & 2 \\
\hline Cumberland & 0 & 1 & 0 & 0 & 0 & 1 \\
\hline Falmouth & 0 & 1 & 0 & 0 & 1 & 2 \\
\hline
\end{tabular}


Table 2.1 Continued

\begin{tabular}{|l|l|l|l|l|l|l|}
\hline Gorham & 0 & 0 & 1 & 0 & 1 & 2 \\
\hline Scarborough & 0 & 1 & 1 & 1 & 1 & 4 \\
\hline Windham & 0 & 0 & 1 & 1 & 1 & 3 \\
\hline Topsham & 0 & 1 & 0 & 0 & 1 & 2 \\
\hline Saco & 0 & 1 & 1 & 1 & 1 & 4 \\
\hline Cape Elizabeth & 0 & 0 & 0 & 0 & 0 & 0 \\
\hline Yarmouth & 0 & 1 & 0 & 0 & 0 & 1 \\
\hline Biddeford & 0 & 0 & 0 & 0 & 0 & 0 \\
\hline Westbrook & 0 & 1 & 1 & 0 & 1 & 3 \\
\hline Lewiston & 0 & 0 & 0 & 0 & 0 & 0 \\
\hline Portland & 0 & 1 & 1 & 1 & 1 & 4 \\
\hline South Portland & 0 & 1 & 1 & 1 & 1 & 4 \\
\hline Bath & 0 & 0 & 0 & 0 & 0 & 0 \\
\hline Old Orchard Beach & 0 & 0 & 0 & 0 & 0 & 0 \\
\hline
\end{tabular}

\section{Data Sources.}

Geographic. I used ArcGIS 10.5 for spatial analyses and to create maps of the Casco Bay Region, including portions of Cumberland, Sagadahoc, Androscoggin, and York Counties, as defined by bounds that included all archaeological sites in the study. All geographic layers and shapefiles were obtained from the Maine Office of GIS, including state outlines, highways, lakes, rivers, and ponds, with the exception of county and town boundaries sourced from the United States Department of Agriculture Forest Service (U.S. Department of Agriculture Forest Service 2009). Satellite. Satellite-derived raster imagery depicting impervious surface change was sourced from the National Land Cover Database for the periods 2001-2006 and 2006-2011. Population Demographics. Population demographic data for the period of 1950-2010 are from the U.S. Census Bureau, and population change over time was calculated for each decade (e.g., 1990-2000). Change in housing unit counts at the town level were calculated on a decadal basis from 1970-2010 (U.S. Census Bureau 2016). 
Archaeological Sites. MHPC and the University of Southern Maine provided archaeological site locations $(n=883)$. Digital spreadsheets from MHPC included UTM coordinates (and other relevant information) for archaeological sites located within the former USGS 15-minute quadrangle maps of Portland, Casco Bay, Freeport, and Bath. These locations were imported and displayed in ArcMap as points for analysis, but are represented as half-kilometer size squares, to protect the exact site locations, per Maine statute (27MRSA371-378). Sites located during 1987-1992 walking surveys of Casco Bay by the University of Southern Maine were digitized from field and laboratory maps. In addition to UTM coordinates, other pertinent site information such as faunal and shell remains by species, site elevation, and site age were linked to these records in Excel and in ArcMap. These sites were symbolized using the same methods outlined above.

\section{Identification of Risk Characteristics.}

1. Low Property Tax Valuation. Low property taxes are an economic incentive for relocation (Boyle et al. 2006). Incorporation of tax records at the town level from 2004-2015 enabled comparison of finer scale trends in socio-economic drivers with population data to determine if property valuation significantly influences migration and growth (Maine Revenue Services 2015). An average property tax threshold was determined by averaging tax values of all towns within the study area; 1 point was assigned for towns with property tax valuation below this amount, while towns with average or above average taxes were assigned a 0 for this category. 2. Turnpike Town. Evaluating census records, Dailey et al. (2012) noted increased growth in turnpike towns since 1990 (with an acceleration of this trend in the most recent decade) relative to surrounding towns with no direct access to the interstate, even though these towns 
may be closer to economic hubs such as Portland. They also noted that this phenomenon is closely linked to populations in metropolitan and economic hubs such as Portland. Towns with direct interstate access (meaning the interstate or access ramp passes through town borders) were assigned 1 point.

3. Rapid Population Growth. This study incorporates decadal population and housing data at the town level. Categories of growth (decline, slow, moderate, rapid) are based on Census records for Northeast regional growth (3.2\%) and national growth (9.7\%) (Mackun, Wilson 2011). Dailey et al. (2012) show that rapid population growth results from more year-round residents, rather than summer-only occupation. Archaeological sites are more likely to be disturbed due to increased population density and its secondary effects such as road and other infrastructure construction. To quantify rapid growth, towns demonstrating rapid increases in population (conservatively assigned a high cut-off value, details follow) during the most recent decade (2000-2010) were selected as those at risk (assigned a value of ' 1 ' in the risk matrix). Demographic data for the period of 1950-2010 were obtained from the US Census Bureau. Population values for each town were evaluated for each decade and population change over time was calculated for each subsequent decadal period (i.e. 1950-1960). Overall statistics of change were compared to change during more recent decades (1990-2000, 2000-2010). Categories of population growth were determined from US Census Bureau national averages. It should be noted that the US Census Bureau's category for "decline" indicates that local populations are growing at a rate slower than the national population growth of $3.2 \%$ and does not necessarily mean that population counts are actually decreasing. The term decline used for 
this study area therefore indicates a decline relative to the national average. Categories of change are as follows:

Decline: $<3.2 \%$

Slow Growth: $3.2 \%<x<9.7 \%$

Moderate Growth: $9.7 \%<x<50 \%$

Rapid Growth: > 50\%

Though trends in previous decades (i.e. 1990-2000) show increasing population density in coastal counties, more recent trends (2000-2010) indicate declines in these counties and corresponding increases in inland counties in Southern Maine (Dailey et al. 2012). At a higher resolution, it becomes apparent that while population is decreasing in coastal counties and increasing in interior ones, population density in the urban, metro areas of coastal counties is growing (2000-2010). At the decadal resolution of census data, it is difficult to determine if socio-economic or physical drivers related to SLR are beginning to influence population movement. Current levels of climate-driven migration (e.g. movement away from the coast due to rising expenses associated with protecting or relocating coastal homes from erosion or chronic flooding, or the difficulty of conforming with coastal building laws) are difficult to distinguish from general migration (e.g. between rural and urban areas). Evaluating population movement and growth at the town level helps distinguish between coastal and inland towns in coastal counties, but data aggregation may hide developing trends. The American Fact Finder, part of the American Community Survey, offers annual population estimates from the period 2009 to present based on census values, but these inter-decadal extrapolations carry too much uncertainty at the fine scales investigated in this research (American Community Survey 2010). 
4. Rapid Construction of Housing Units. Like population, housing unit density in urban cores is also increasing, with new units constructed at annual rates higher than in previous decades (Dailey et al. 2012). This replaces previous trends of higher construction rates in suburban areas (Dailey et al. 2012). However, construction trends do not match population trends. Despite concentrations of growth in pre-existing urban centers, particularly in the city of Portland, a recent trend (2000 to present) is that for every additional person counted in the census, multiple housing units are constructed. Sagadahoc County has the highest ratio of housing units to individuals in the state; for every new individual, 22.8 new housing units are built (Dailey et al. 2012). Construction typically lags behind population growth, but a drastic increase in seasonal homes in some Maine counties have caused housing growth to outpace population growth in some areas (Dailey et al. 2012). Determining when construction is driven by tourism and when it reflects changes in lifestyle priorities for residents is difficult. The American Community Survey offers annual housing and residency projections based on census data, but the decadal census surveys offer the only true records of housing patterns at the town level, nationwide. Because these shifts in the rental and vacation market are occurring at frequencies greater than decadal, it is not possible to systematically track these changes at the resolution required in this study; aggregation of data hides finer scale trends of interest. Furthermore, both population and in-migration during the $2000-2010$ census period were impacted by the 2007-2009 recession (Dailey et al. 2012).

As with population growth statistics, increases in housing unit construction were quantified per U.S. Census Bureau standards for Northeast regional growth (6.6\%) and national growth (13.6\%) of housing unit construction (Mazur, Wilson 2011). Rapid construction of 
housing units and commercial and industrial buildings, and their associated infrastructure often results in unplanned or poorly managed urban development and construction, termed "urban sprawl" (Savage, Lapping 2003). Savage and Lapping refer to this process as "a fragmented, piecemeal, uncoordinated, unplanned, and inefficient land use process", arguing that it "follows the path of least resistance when confronting the land use regulatory system" (Savage, Lapping 2003). Higher rates of construction also mean higher amounts of disturbed land, increasing the likelihood of potential site destruction. Towns with recent decadal trends in rapid housing unit growth during the most recently reported decadal census were assigned a value of ' 1 ' (risk).

Decadal housing unit values were only available from 1970-2010 at the town level, and change over time was calculated for 1970-1980, 1980-1990, 1990-2000, and 2000-2010 (U.S. Census Bureau: American Community Survey 2010). As with population growth statistics, categories of housing unit change were quantified per U.S. Census Bureau standards for growth (U.S. Census Bureau, October 2011) and are as follows:

Decline: $<6.6 \%$

Slow Growth: $6.6 \%<x<25 \%$

Moderate Growth: $25 \%<x<50 \%$

Rapid Growth: > 50\% 
Figure 2.1: Population Growth and Housing Unit Construction in Southern Maine, 2000-10. See

Table A in the Appendix for a map legend with town names.

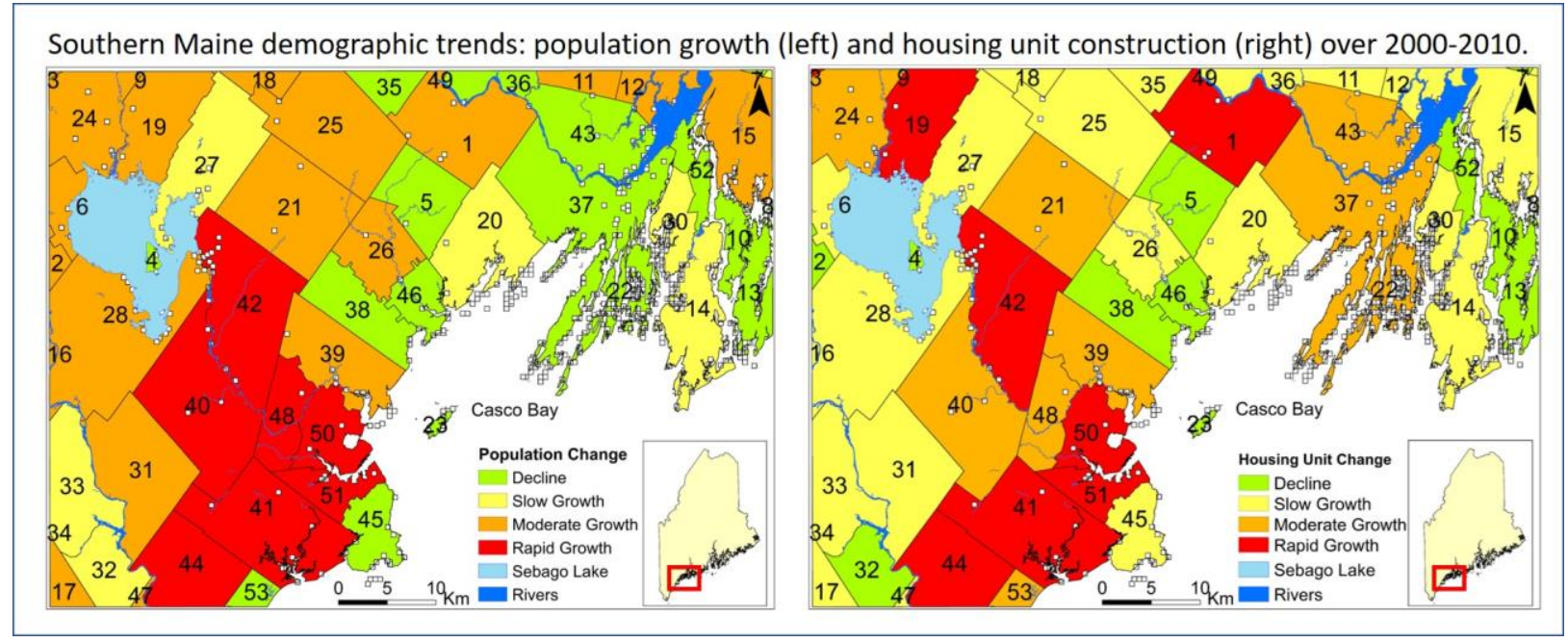

Divergent trends in population (left) and housing unit construction (right) shown in Figure 2.1 above during the same period (2000-2010) show the importance of evaluating multiple socio-demographic factors (Mackun, Wilson 2011). Rapid increases in housing units in towns with slow or moderate population change are likely due to an increase in seasonal homes (Dailey et al. 2012). See Table A in the Appendix for a table with map names.

5. Increase in Impervious Surfaces Relative to Surrounding Towns. Impervious surfaces are generally artificial, impenetrable structures such as asphalt parking lots, buildings, and roads, through which water cannot pass. Construction of infrastructure destroys archaeological sites. Urban areas feature a high percentage of this land cover type, which can be quantified via satellite imagery using their reflective properties. Unlike metrics which directly measure population or housing counts, tracking increases in impervious surfaces enables monitoring of associated urban infrastructure that may be expanding faster than populations, such as roads, 
parking lots, industrial buildings, electrical and pipeline corridors, energy generation plants, waste and sewage facilities, etc. (Song et al. 2016). This is an indirect, but strongly correlated indicator of development (Song et al. 2016), and thus serves as another metric by which to gauge climate-driven migration.

The National Land Cover Database (NLCD), produced by the Multi-Resolution Land Characteristics Consortium, enables analysis of impervious surface change at a 30-meter by 30-meter resolution across the conterminous United States (Xian et al. 2011). Produced at 5year intervals, this Landsat-derived product provides percent developed imperviousness estimates that are associated with urban land cover expansion for 2001, 2006, and 2011 (Xian et al. 2011). 2016 data are expected to be released in the near future. NLCD satellite-derived impervious surface change data were selected for this study because these raster data are available with national coverage at intervals of 5 years and will continue to be produced systematically with consistent methodologies (Xian 2011). While multiple categories of impervious surface development per 30m pixel are quantified in the NLCD-produced impervious surface raster data, for the purposes of this research, any increase of impervious surfaces of any category of development were counted when quantifying total increase in impervious surfaces. Declines in impervious surfaces (removal of a parking lot and replacement by grass, for example) were not considered because modification of undeveloped or less-developed land is the metric of interest within the context of archaeological site disturbance. Once land has been built upon (leveled, paved over, or excavated for construction), sites have been destroyed. Even if a parking lot is ultimately remediated into a 
wetland, the fact remains that the original archaeological site has already been impacted or destroyed.

To assess impervious change, I downloaded NLCD Percent Developed Imperviousness Change 2001-2006 and 2006-2011 products and clipped them to the study area. I reclassed raster pixels to exclude water bodies and classified all levels of developed impervious surfaces as ' 1 ', while non-impervious surfaces (grassland, forest, etc.) were classified as ' 0 '. I converted the resulting rasters into polygons and tabulated total impervious areas by town. I joined the resulting tables with a shapefile containing spatially-referenced town information, and total impervious surface area increase over the period 2001-2011 was calculated for each town. I classified towns using a standard deviation classification: those with higher than average increases in impervious surfaces relative to other towns in the study area were designated as a risk of ' 1 ' in the risk matrix table, while towns with below average increases were assigned ' 0 '.

While Maine's Site Location Law requires MHPC review of any development with over 7 acres of impervious surfaces, tracking higher than average increases by town over time as a criterion for risk provides another independent proxy for development (Maine Department of Environmental Protection 2018). MHPC uses predictive modeling to assess the likelihood of existence of unreported Native American archaeological sites when reviewing land development proposals, and recommends test pits and excavations accordingly (personal communication, Arthur Spiess). Despite this proactive approach, sites are still uncovered during development (personal communication, Arthur Spiess). Given the direct cause-and-effect between land development and archaeological site discovery, archaeological sites in towns with higher trends in infrastructure development are at higher risk for destruction than those in 
towns with a lower increase in impervious surfaces. It is important to note that while this approach doesn't integrate Colonial European sites, the same principle applies.

Biases in Chosen Risk Factors. Some categories of risk were omitted from this pilot study, such as socio-economic drivers of migration like quality of school district, public transit, or medical services. While these may be considered strong "pull factors" for migration in some areas, they may be less important in other regions. Because this study was designed to be applicable at a national scale, I have left out factors that are not equally applicable across the entire coastal U.S., to allow this framework to be applied in many diverse regions. However, town- or regionspecific factors could be added to the risk matrix for regions in which they are appropriate. 


\section{CHAPTER 3}

\section{RESULTS}

\section{Scaled Risk}

I assessed potential population resettlement and related risk to cultural resources using five factors. Each was equally weighted, with ' 1 ' assigned to towns meeting the particular criterion (' 1 ' representing risk), and ' 0 ' assigned to towns that did not meet that criterion. This risk matrix generated a scale of risk for towns, ranging from 0-5, with lower rankings indicating less risk posed to archaeological sites within a town due to climate-driven resettlement by 2100 (figure 2). This scale of risk corresponds to categories of "High Risk" (5), "High Moderate Risk" (4), “Moderate Risk" (3), “Low Moderate Risk" (2), “Low Risk” (1), and “No Risk” (0). 


\section{Results of the Weighted Risk Matrix}

Figure 3.1: Summed Risk Matrix Results

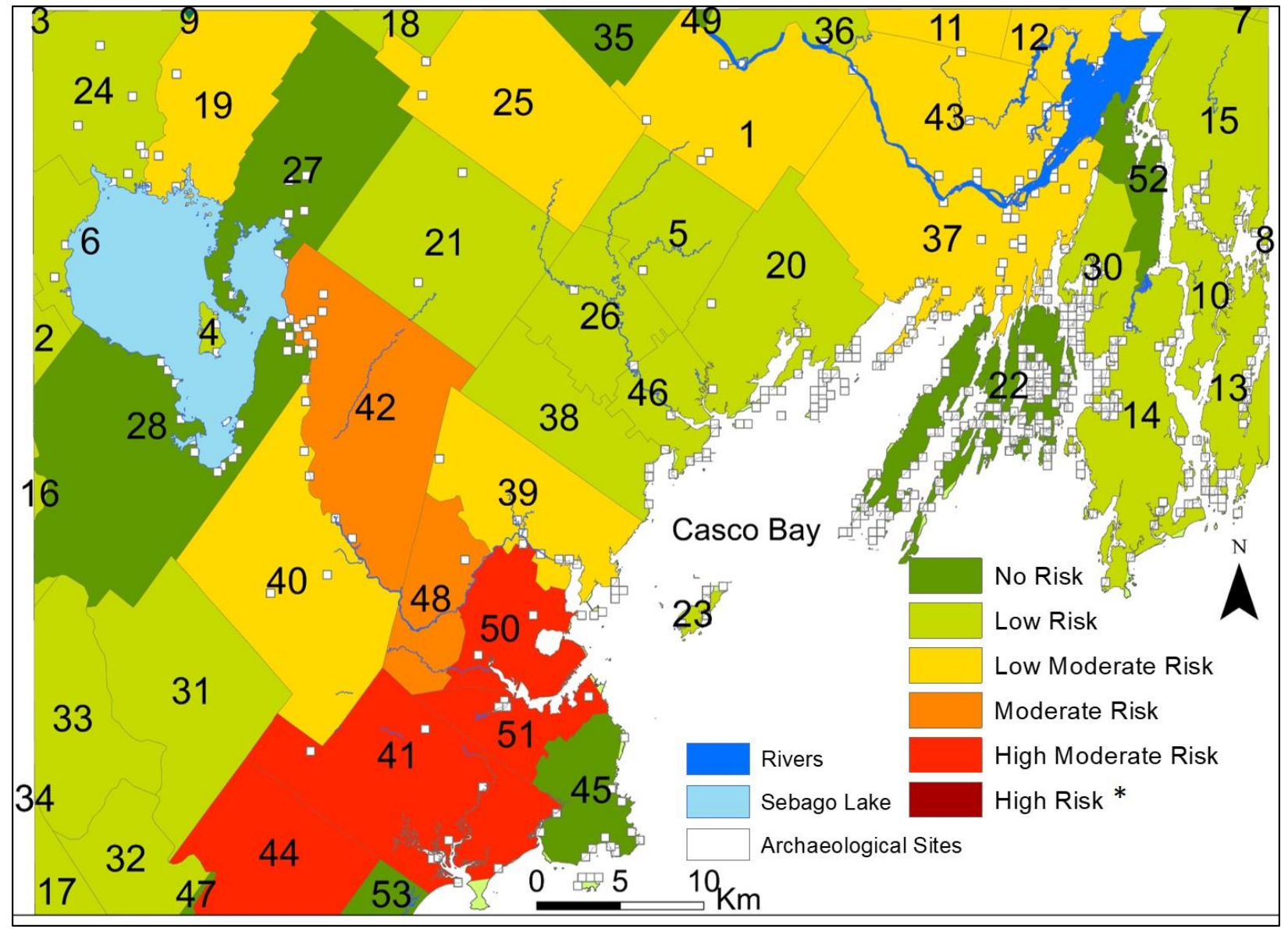

* There were no 'High Risk' towns (see Chapter 4 Discussion “Results of the Weighted Risk

Matrix" below). See Table 2.1 for summed risk matrix which produced this map.

High Risk. None of the 52 towns in the study area received a ' 1 ' score in all five categories.

High Moderate Risk. While no town fit the highest category of risk on the basis of summed risk categories, four towns in the southern portion of the Casco Bay region were categorized as

'High Moderate Risk', with scores of '4': Scarborough, Saco, Portland, and South Portland (see

Figure 3.1 above and Table A.1 for a legend listing town names corresponding to map symbols). 
Each of these towns meets four of the five criteria for risk. All towns had the same four risk indicators (turnpike towns, population increase, housing unit increase, and increase in impervious surfaces), while none received a ' 1 ' in the low property tax category. It is important to note that while Portland and South Portland both have sizable urban areas, they also have less densely populated regions in their interior portions.

Moderate Risk. Two 'Moderate Risk' towns (score of '3') Windham and Westbrook, are both interior, and are in the highest category of population growth during the most recently recorded decade (1990-2000) and had moderate to rapid growth in housing unit construction during this time (growth categories are based on a U.S. Census brief, see Methods Chapter 3 for details).

Low Moderate Risk. In the 'Low Moderate Risk' ('2') category are Bowdoin, Bowdoinham, Brunswick, Casco, Durham, Falmouth, Gorham, New Gloucester, Topsham, and Waterboro. Bowdoinham, Topsham, and Brunswick are located on Merrymeeting Bay, while Brunswick also has a sizeable coastline on Casco Bay. Falmouth is also a coastal town, but like the other three towns, also has large swaths of interior, undeveloped acreage as seen in impervious surface satellite data. Archaeological sites will be threatened by development in these interior areas. In the southwestern corner of the study area, Waterboro's land area is clipped too small by the study zone boundary to be used in this study because there is not enough acreage to accurately assess impervious surface change (criteria 5).

Low Risk and No Risk. Several of the 'Low Risk' and 'No Risk' towns (categories ' 1 ' and '0') in the northern and northwest interior (e.g. Baldwin) likely have artificially low scores because their town boundaries are also clipped by the study area. Future statewide assessments can 
avoid artificial boundary issues, but because the clipped land areas did not affect spatial relationships within the risk matrix, I did not consider this to be problematic for constructing this threat scale or for prioritizing sites at risk of destruction. 


\section{CHAPTER 4 \\ DISCUSSION}

\section{Products of the Risk Assessment Framework}

The summed risk matrix described in the Chapters 2 and 3 allows municipal, county, and state government planners to identify towns where climate-driven increases in population and infrastructure density are most likely to threaten archaeological sites throughout this century. The scaled risk maps I produced via this framework can enable communities and local and state officials to prioritize cultural resource management and stewardship in areas where archaeological sites are most threatened by destruction.

\section{Implications of Risk Assessment Scale}

Regulatory bodies, such as the Maine Historic Preservation Commission, are able to examine which towns have archaeological sites that fall within the higher risk categories (3-5). Due to limited funding available for archaeological research, this framework is also important because it enables archaeologists and cultural resource managers to prioritize regions for survey, as well as identify individual sites for further research and conservation.

\section{High Moderate Risk Towns}

Under the criteria developed for this case study, towns with archaeological sites at highest risk of destruction (called 'High Moderate Risk') due to climate-driven resettlement are Scarborough, Saco, Portland, and South Portland. In these towns, identified archaeological sites are clustered along waterways, particularly in Portland, South Portland, and Scarborough. In Scarborough, several archaeological sites are recorded in the interior portion of the town, indicating that there may be more sites away from prominent hydrologic features or near the 
marsh, that have not yet been "discovered" or recorded due to a lack of development and, thus, excavation in this area. I note that there are many historic cultural sites in these towns with larger urban centers (e.g. Portland City), but these are not addressed in this pilot study.

All four of these municipalities have cultural resource management provisions included in their zoning and subdivision ordinances. These require that proposed development or soil disturbance "on or adjacent to sites listed on, or eligible to be listed on the National Register of Historic Places" be submitted to the MHPC for review and comment (Town of Portland 2013; Town of Saco 2018; Town of Scarborough 2018; Town of Scarborough 2017; Town of South Portland 2006; Town of South Portland 2017). The MHPC then provides comments on the proposed plans to the permitting authority of the town. The NHPA offers additional layers of management for sites when federal funds or federal permits are involved, including those which do not qualify for National Register listing (Center for Regulatory Effectiveness 2007). Federally-protected Wetlands. While the town of Scarborough is included as a high-risk area for resettlement, it contains a large percentage of federally protected wetlands. The Scarborough Marsh extends inland from the coast and has expected centennial storm surge and flooding increases outside of the boundaries of the marsh. Scarborough's Floodplain Management Ordinance involves federal flood relief funding from the National Flood Insurance Program in areas prone to flooding, such as the Scarborough Marsh Wildlife Management Area (WMA) (Town of Scarborough 2007). Per the National Flood Insurance Act of 1968, any development within flood-prone areas must be assessed by the MHPC, even when federal funds are not involved. In addition, because approximately 3,100 acres of this wetland are owned and managed as a WMA by the Maine Department of Inland Fisheries and Wildlife, this 
land is not considered available for migration or construction (Maine Department of Inland Fisheries and Wildlife 2018). The remaining part of the town, however, is still indicated as a high probability location for climate-induced migration and includes a considerable interior area.

Multiple Levels of Protection. Multiple levels of protection in towns at highest assessed risk of development help safeguard archaeological sites from different modalities of destruction (inadvertent, with data collection, and without data collection). Inadvertent site destruction can occur on private, state, or federal lands, even when phase one surveys have been completed to assess the likelihood of the existence of archaeological sites. In this category of unintentional anthropogenic destruction, a portion of a site may be destroyed before construction is halted to assess the remainder of the location. Despite Maine's proactive approach, sites are still uncovered during development (personal communication, Arthur Spiess). Archaeological sites are also destroyed by environmental and climatic drivers, such as erosion. Like inadvertent destruction, this category of loss also often occurs without data collection. Destruction with data collection occurs when sites are excavated, however records and data collection practices were poorer in previous decades, thus reducing the amount of information and samples that were obtained from a site. In regions in which overlapping federal, state, and municipal protections do not exist, the likelihood of inadvertent site destruction - or destruction without data collection - increases.

Site Location Law. While Maine's Site Location Law offers protection for known and likely archaeological sites against development at the state level, many states in the nation don't have such proactive plans in place for cultural resource stewardship. Though this risk framework may disproportionately benefit states without regulations like Maine's Site Location 
Law, the guidelines proposed by the risk framework developed in this study can enable prioritization of cultural resource management at the town and county level anywhere in the United States. Such proactive measurements can help avoid costly economic delays when new sites are found during construction.

\section{Moderate Risk Towns}

The 'Moderate Risk' category identifies towns within which cultural resources are at a concerning level of risk due to climate-driven migration, and towns falling within this category should strengthen measures for archaeological site stewardship. In this pilot study, two towns are categorized as risk level '3': Westbrook and Windham. While Westbrook has only one recorded site location (not near a major waterway), Windham has many, due to the presence of the Saco River in the town and the sites discovered there during construction projects with federal funding (e.g. hydroelectric dam relicensing). The majority of Windham's archaeological sites appear to be located along major waterways, leaving the possibility that sites exist within the undeveloped rural areas of the town (Kellogg, 1987). Here, land use ordinances offer good protections for archaeological sites against development threats (Town of Westbrook 2018; Town of Windham 2009).

\section{Low Moderate Risk Towns}

While cultural resources in Low Moderate Risk towns (summed risk of ' 2 ') are likely to experience fewer development threats over the remainder of the century due to climate-driven relocation, local and state laws protecting archaeological sites should nonetheless be examined, and stewardship plans proposed for these areas. As stated above, many parts of the country do not benefit from the same proactive rules and practices governing cultural resources that exist 
within this pilot study area (municipal growth management plans that incorporate cultural resources, State-level Site Location Laws, or predictive modeling of archaeological site locations and recommended surveys). In areas lacking these measures, risk identification frameworks like this study will be even more important.

Archaeological sites in these towns are generally located away from major hydrologic features and in areas where their "discovery" was caused by development surveys or other pressures. As mentioned previously, it is likely that many other sites exist in the landscape but are unrecorded.

\section{Low and No Risk Towns}

These two categories of town are at relatively low risk for climate-driven in-migration. While these towns, their cultural resources, and their municipal development plans should not be ignored, other towns in a region are indicated to be at a higher likelihood for development, and thus and archaeological sites within these towns are at a higher risk for destruction. 


\section{CHAPTER 5}

\section{CONCLUSION}

\section{Accessible Analysis Framework}

Because this framework uses public and nationally-available data, it presents an accessible method of highlighting towns (or townships in some states) where sites will be most threatened by development (for the purposes of this study, this means evaluating categories 35 (Moderate Risk, High Moderate Risk, and High Risk) for the area of interest.

\section{Framework May be Updated as New Data is Released}

This framework is easy to update when new data become available, such as the next decadal 2010-2020 census. As risk factors are updated, users may see changes in the rankings of towns in their region(s) of interest that can continue to help guide stewardship and urban planning efforts.

\section{Use by Communities, Agencies, and Urban Planners}

In addition to informing landowners and communities about the existence of threatened archaeological sites before zoning and development plans are in place, this method will also help justify state-level survey time and expenses in these towns in advance of development. Additionally, this risk matrix may be used by the MHPC, or similar agencies in other states, to prioritize locations for surveys and excavations to assess the eligibility of sites for National Register listing within a town or group of towns based on the likelihood of climatedriven migration (more below). This product addresses a growing need for cultural resource prioritization strategies as a component for stewardship and climate strategies (Heilen et al. 2018; Howard 2013; Reeder-Myers 2015). My analysis of the secondary effects of climate 
change can also be integrated into long-term growth management plans and other regional and state planning documents. It is imperative for archaeologists to work with climate scientists, urban planners, communities, and government officials alike to identify and protect these sites and to increase stewardship of our archaeological heritage, in Maine, and in coastal zones throughout the U.S. and elsewhere.

\section{Next Steps}

The next steps for this research include 1) broadening the scope of the project to a wider geographic area to test applicability, and 2) including state and local stakeholders to investigate the feasibility of adopting these strategies at the town level. This effort will require a strong public education component, as it is likely that individual towns may not be aware of cultural resources within town boundaries or have even contemplated the value of these resources to a sense of place or continuity. Since the Maine Historic Preservation Commission has already demonstrated interest in this project, working first with that agency and towns with already implemented cultural resource plans in place may be the best place to start. Statewide conservation organizations, such as Maine Audubon, the Nature Conservancy, as well as local land trusts may be allies in this endeavor, as protected archaeological sites may also represent conserved landscapes in the face of migration-driven development.

It is imperative, however, that this work begins quickly. Primary impacts of climate change are already experienced on the Maine coast. As these impacts become more severe, populations will respond by moving from the damage zone. If this response is undertaken as a reaction to crisis, rather than as a carefully considered plan, it may be too late to preserve cultural resources from the secondary effects of climate change. 


\section{REFERENCES}

Aerts J (2017) Climate-induced migration: Impacts beyond the coast. Nat Clim Change, 7(5): 315-316. [Accessed April 30, 2018].

Alaska Native Tribal Health Consortium Center for Climate and Health (2011) Climate Change in Kivalina, Alaska: Strategies for Community Health (ANTHC Center for Climate and Health) Available at:

http://www.cidrap.umn.edu/sites/default/files/public/php/26952/Climate\%20Change\%20HIA \%20Report_Kivalina.pdf [Accessed April 30, 2018].

Anderson D, Bissett T, Yerka S, Wells J, Kansa E, Kansa S, Myers K, DeMuth R and White D (2017) Sea-level rise and archaeological site destruction: An example from the southeastern United States using DINAA (Digital Index of North American Archaeology). PLOS ONE, 12(11), pp.1-25. [Accessed April 30, 2018].

Boyle K, Bell K, Rubin J (2006) Economics of Rural Land-Use Change (Ashgate Press, Chippenham, Wiltshire).

Center for Regulatory Effectiveness (2007) Archaeological and Historic Preservation Act of 1974. Available at: http://www.thecre.com/fedlaw/legal13/archpreserv.htm [Accessed February 18, 2018].

Cox Jr, Anthony L. (2008). What's wrong with risk matrices?. Risk Analysis: An International Journal, 28(2), 497-512.

Dailey A, Hastings S, Lloyd S, McWilliams N and Workman S (2012) Changing Maine: Maine's Changing Population and Housing 1990-2010 (Muskie School of Public Service, University of Southern Maine) Available at: https://umaine.edu/mitchellcenter/wpcontent/uploads/sites/293/2013/08/Census_Report_1012121.pdf [Accessed April 30, 2018].

Dickson S M (2018) Coastal Erosion Assessment for Maine FIRMs and Map Modernization Plan (Maine Geological Survey) Available at: https://www.maine.gov/dacf/mgs/explore/marine/ firms/2003_coastal_erosion_assessment_for_firms.pdf [Accessed April 30, 2018].

Digital Maine. (2018). State Planning Office. Retrieved May 2, 2019, from https://digitalmaine.com/spo_docs/

Döös B R (1997) Can large-scale environmental migrations be predicted?. Glob Environ Change 7(1):41-61. [Accessed April 30, 2018]. 
Federal Emergency Management Agency (2014) Flood Risk Report: Cumberland County, Maine Flood Risk Project (Report No. 1). Available at: https://map1.msc.fema.gov/data/FRP/ FRR_23005C_20140930.pdf?LOC=ef32857d352e428d9fb44b02ba3aaa19 [Accessed October 11, 2018].

Graham G (2018) After losing ground for decades, Camp Ellis feeling helpless. Retrieved April 30, 2019, from Press Herald website: https://www.pressherald.com/2018/04/15/after-losingground-for-decades-camp-ellis-feeling-helpless/

Greater Portland Council of Governments (2013) Sea Level Rise Vulnerability Assessment (Sustain Southern Maine) Available at: https://www.cascobayestuary.org/wpcontent/uploads/2015/10/SSM-Sea-Level-Rise-Vulnerability-Assessment_FINAL.pdf [Accessed September 1, 2018].

Hauer M E (2017) Migration induced by sea-level rise could reshape the US population landscape. Nat Clim Change 7:321-325. [Accessed April 30, 2018].

Heilen M, Altschul, J H, and Lüth F (2018) Modelling Resource Values and Climate Change Impacts to Set Preservation and Research Priorities. Conservation and Management of Archaeological Sites, 20(4), 261-284.

Henselwood F and Phillips G (2006) A matrix-based risk assessment approach for addressing linear hazards such as pipelines. Journal of loss prevention in the process industries, 19(5), 433441.

Howard A J (2013) Managing Global Heritage in the Face of Future Climate Change: The Importance of Understanding Geological and Geomorphological Processes and Hazards. International Journal of Heritage Studies 19 (7): 632-658. doi:10.1080/13527258.2012.681680.

Intergovernmental Panel on Climate Change (2014) Climate Change 2014: Synthesis Report. Contribution of Working Groups I, II and III to the Fifth Assessment Report of the Intergovernmental Panel on Climate Change [Core Writing Team, R K Pachauri and L A Meyer (eds.)]. (IPCC, Geneva). Available at https://www.ipcc.ch/pdf/assessmentreport/ar5/syr/SYR_AR5_FINAL_full_wcover.pdf. [Accessed September 1, 2018].

Katz D (2017) The National Flood Insurance Program: Drowning in Debt and Due for Phase-out. The Heritage Foundation. Available at: https://www.heritage.org/governmentregulation/report/the-national-flood-insurance-program-drowning-debt-and-due-phase-out [Accessed September 1, 2018].

Kaufman B, Kelly C S, and Vachula R S (2018) Paleoenvironment and Archaeology Provide Cautionary Tales for Climate Policymakers. Geogr Bull 59(1). 
Kellogg D C (1987) Statistical relevance and site locational data. American Antiquity, 52(1), 143150.

Knutson T, McBride J L, Chan J, Emanuel K, Holland G, Landsea C, Held I, Kossin J P, Srivastava A K, Sugi M (2010) Tropical cyclones and climate change. Nat Geosci 3:157-163.

Lentz E E, Thieler E R, Plant N G, Stippa S R, Horton R M, and Gesch D B (2016) Evaluation of dynamic coastal response to sea-level rise modifies inundation likelihood. Nat Clim Chang 6:696-700.

Li K X, Cullinane K, and Nielsen D (2002) An Economic Approach to Maritime Legal Liability (International Association of Maritime Economists (IAME), International Steering Committee, Panama).

Mackun P, Wilson S (2011) 2010 Census Briefs: Population Distribution and Change: 2000 to 2010 (U.S. Census Bureau Report No. C2010BR-01). Available at: http://www.census.gov/prod/cen2010/briefs/c2010br-01.pdf

Maine Department of Environmental Protection (2014) Chapter 355: Coastal Sand Dune Rules. Available at: https://www.maine.gov/sos/cec/rules/06/096/096c355.doc [Accessed October 9, 2018].

Maine Department of Environmental Protection (2018) Site Location of Development: Title 38, Chapter 3, §§ 481-490. Available at: https://www.maine.gov/dep/land/sitelaw/index.html [Accessed October 10, 2018].

Maine Department of Inland Fisheries and Wildlife (2018) Scarborough Marsh WMA. Available at:

https://www.maine.gov/ifw/fish-wildlife/wildlife/lands/wildlife-management-areas/regiona/scar borough.html [Accessed March 24, 2018].

Maine Revenue Services (2015) State Valuation History 2004 - 2015. Available at: http://www.maine.gov/revenue/propertytax/ [Accessed March 14, 2016].

Maine State Planning Office (2006, March) An Evaluation of the Growth Management Act and its Implementation. Retrieved from https://www.maine.gov/dacf/municipalplanning/docs/ growthmanagementactevaluationreport.pdf

Maio C V, Gontz A M, Tenenbaum D E, and Berkland E P (2012) Coastal Hazard Vulnerability Assessment of Sensitive Historical Sites on Rainsford Island, Boston Harbor, Massachusetts. Journal of Coast Research 28 (1A): 20-33. doi:10.2112/JCOASTRES-D-10-00104.1. 
Mazur C, Wilson E (2011) 2010 Census Briefs: Housing Characteristics: 2010

(U.S. Census Bureau Report No. C2010BR-07). Available at:

https://www.census.gov/prod/cen2010/briefs/c2010br-07.pdf

Moser S (2005) Impact assessments and policy responses to sea-level rise in three US states: An exploration of human-dimension uncertainties. Glob Env Chang 15:353-369.

Murdukhayeva, August A P, Bradley M, LaBash C, and Shaw N (2013) Assessment of Inundation Risk from Sea Level Rise and Storm Surge in Northeastern Coastal National Parks. Journal of Coastal Research 29 (6a): 1-16. doi:10.2112/JCOASTRES-D-12-00196.1.

NANA Regional Corporation, Inc. (2016) Kivalina. Available at: http://nana.com/regional/aboutus/overview-of-region/kivalina/ [Accessed September 1, 2018].

National Oceanic and Atmospheric Administration (2017) Major Hurricane Harvey - August 25-29, 2017. Available at https://www.weather.gov/crp/hurricane_harvey [Accessed March 23, 2018].

Reeder-Myers L A (2015) Cultural Heritage at Risk in the Twenty-First Century: A Vulnerability Assessment of Coastal Archaeological Sites in the United States. The Journal of Island and Coastal Archaeology 10: 436-445. doi:10.1080/15564894.2015.1008074.

Rockman M (2015) An NPS Framework for Addressing Climate Change with Cultural Resources. George Wright Forum 32: 37-50.

Russell, E., \& Miller, K. (2019, January 22). Sea-level rise hurting Maine's waterfront real estate values. Retrieved April 29, 2019, from Press Herald website:

https://www.pressherald.com/2019/01/22/sea-level-rise-hurting-maine-real-estate-values/

Sandweiss D H and Kelley A R (2012) Archaeological Contributions to Climate Change Research: The Archaeological Record as a Paleoclimatic and Paleoenvironmental Archive. Annu Rev Anthropol 41:371-391.

Savage L, Lapping M (2003) in Suburban Sprawl: Culture, Theory and Politics, Lindstrom M, Bartling Hed (Rowman \& Littlefield Publishers, Lanham), pp 5-17.

Schauffler, M. (2017, September 17). Climate refugees could see safety in Maine. Press Herald. Retrieved from https://www.pressherald.com/2017/09/17/ sea-change-climate-refugeescould-see-safety-in-maine/

Slovinsky, P. (2005). Maine Geological Survey: Coastal Processes and Beach Erosion. [online] Maine Geological Survey. Available at: https://www.maine.gov/dacf/mgs/explore/marine/ virtual/saco/virtual_saco_bay.pdf [Accessed 11 Oct. 2018]. 
Society for American Archaeology. (2019). Committee on Climate Change Strategies and Archaeological Resources. Retrieved May 2, 2019, from http://ecommerce.saa.org/saa/ SAAMember/Members_Only/CommTaskForce.aspx?Code=CCSAR

Song X, Sexton J, Huang C, Channan S, Townshend J (2016) Characterizing the magnitude, timing and duration of urban growth from time series of Landsat-based estimates of impervious cover. Remote Sensing of Environment 175:1-13.

Tebaldi C, Strauss B, Zervas C (2012) Modelling sea level rise impacts on storm surges along US coasts. Environmental Research Letters 7:014032.

The United Nations Migration Agency (2017) Migration, Climate Change, and the Environment: A Complex Nexus. International Organization for Migration. Available at: https://www.iom.int/complex-nexus [Accessed September 1, 2018].

Town of Portland (2013) Chapter 14 Land Use. Available at: https://www.portlandmaine.gov/DocumentCenter/View/3411/Land-Use-Code-Zoning?bidld= Town of Saco (2018) Chapter 230: Zoning. Available at: http://ecode360.com/32483142

Town of Scarborough (2018) Chapter 405 Town of Scarborough Zoning Ordinance. Available at: http://www.scarboroughmaine.org/town-government/town-ordinances

Town of Scarborough (2007) Chapter 405A Town of Scarborough Floodplain Management Ordinance. Available at: http://www.scarboroughmaine.org/town-government/townordinances

Town of Scarborough (2017) Chapter 406 Town of Scarborough Subdivision Ordinance. Available at: http://www.scarboroughmaine.org/town-government/town-ordinances

Town of South Portland (2006) Chapter 24: Subdivisions. Available at: http://www.southportland.org/our-city/code-ordinance/

Town of South Portland (2017) Chapter 27: Zoning. Available at: http://www.southportland.org/our-city/code-ordinance/

Town of Westbrook (2018) Land Use Ordinances of the City of Westbrook. Available at: http://www.westbrookmaine.com/DocumentCenter/View/1170/Appendix-A-Land-UseOrdinance--2070207

Town of Windham (2009) Land Use Ordinance: Chapter 140 From the Code of the Town of Windham. Available at: http://www.windhammaine.us/DocumentCenter/View/533 
Union of Concerned Scientists (2017) Massachusetts Faces Chronic Inundation. Available at: http://www.ucsusa.org/RisingSeasHitHome [Accessed February 18, 2018].

U.S. Census Bureau; American Community Survey 2010 Demographic Profile, Table DP-1; generated by Ani St. Amand; using American FactFinder (2016). Available at:

http://factfinder2.census.gov [Accessed January 12, 2016].

U.S. Census Bureau (1994) Chapter 8: County Subdivisions. Available at:

https://www2.census.gov/geo/pdfs/reference/GARM/Ch8GARM.pdf [Accessed April 25, 2018].

U.S. Census Bureau(2012, August).2010 Census of Population and Housing: Maine: 2010

Population and Housing Unit Counts (Report No. CPH-2-21) (U.S. Census Bureau, Author).

U.S. Climate Resilience Toolkit (2017) Relocating Kivalina. Available at:

https://toolkit.climate.gov/case-studies/relocating-kivalina [Accessed October 15, 2017].

U.S. Department of Agriculture Forest Service Northern Research Station Unit 08

(2009) County Subdivision [Shapefile]. Available at http://www.nrs.fs.fed.us/data/urban

United States Department of Agriculture. (n.d.). Maine - Rural Definitions: State-Level Maps

(United States Department of Agriculture, Author). Retrieved from

https://www.ers.usda.gov/webdocs/DataFiles/53180/25574_ME.pdf?v=0

U.S. Department of Housing and Urban Development (2014) Climate Change Adaptation Plan Available at: https://www.hud.gov/sites/documents/HUD2014CCADAPTPLAN.PDF

U.S. Department of Housing and Urban Development (2016) National Disaster Resilience Competition Grantee Profiles Available at https://www.hud.gov/sites/documents/ NDRCGRANTPROF.PDF [Accessed September 1, 2018].

Vermeer M, Rahmstorf S (2009) Global sea level linked to global temperature. Proc Natl Acad Sci 106:21527-21532.

Wang J J (2015) Flood Risk Maps to Cultural Heritage: Measures and Process. Journal of Cultural Heritage 16: 210-220. doi:10.1016/j.culher.2014.03.002.

White E (2006) Forests on the edge: a case study of south-central and southwest Maine watersheds (USDA Forest Service, Pacific Northwest Research Station) Available at:

https://www.fs.fed.us/openspace/fote/maine-casestudy-ew-062506.pdf [Accessed September $1,2018]$.

Wilson S G, Fischetti T R (2010) Coastline Population Trends in the United States 1960 to 2008. Washington, DC: US Department of Commerce, Economics and Statistics Administration, US Census Bureau. 
Xian G Z, Homer C G, Dewitz J, Fry J, Hossain N, and Wickham J (2011) The change of impervious surface area between 2001 and 2006 in the conterminous United States. Photogramm Eng and Remote Sensing, 77(8): 758-762. 


\section{APPENDIX}

Table A Legend for Figure 2.1.

\begin{tabular}{|c|c|c|c|}
\hline Map Label & Town Name & Map Label & Town Name \\
\hline 1 & Durham town & 27 & Standish town \\
\hline 2 & Baldwin town & 28 & Wiscasset town \\
\hline 3 & Bridgton town & 29 & West Bath town \\
\hline 4 & Frye Island town & 30 & Buxton town \\
\hline 5 & Pownal town & 31 & Dayton town \\
\hline 6 & Sebago town & 32 & Hollis town \\
\hline 7 & Dresden town & 33 & Waterboro town \\
\hline 8 & Westport town & 34 & Auburn city \\
\hline 9 & Arrowsic town & 35 & Lisbon town \\
\hline 10 & Bowdoin town & 36 & Brunswick town \\
\hline 11 & Bowdoinham town & 37 & Cumberland town \\
\hline 12 & Georgetown town & 38 & Falmouth town \\
\hline 13 & Phippsburg town & 39 & Gorham town \\
\hline 14 & Woolwich town & 40 & Scarborough town \\
\hline 15 & Limington town & 41 & Windham town \\
\hline 16 & Lyman town & 42 & Topsham town \\
\hline 17 & Poland town & 43 & Saco city \\
\hline 18 & Casco town & 44 & Cape Elizabeth town \\
\hline 19 & Freeport town & 45 & Yarmouth town \\
\hline 20 & Gray town & 46 & Biddeford city \\
\hline 21 & Harpswell town & 47 & Westbrook city \\
\hline 22 & Long Island town & 48 & Lewiston city \\
\hline 23 & Naples town & 49 & Portland city \\
\hline 24 & New Gloucester town & 50 & South Portland city \\
\hline 25 & North Yarmouth town & 51 & Bath city \\
\hline 26 & Raymond town & 52 & Old Orchard Beach towr \\
\hline
\end{tabular}




\section{BIOGRAPHY OF THE AUTHOR}

Ani St. Amand grew up in Stonington, Maine on Deer Isle. Ani is a candidate for the Master of Science degree in Quaternary and Climate Studies from the Climate Change Institute at the University of Maine in May 2019. After receiving this degree, Ani will continue at the University of Maine in the Interdisciplinary Ph.D. program studying abrupt climate change and human adaptation. Ani is a candidate for the Master of Science degree in Quaternary and Climate Studies from the University of Maine in May 2019. 